\title{
INFLUENCE OF INITIAL STRUCTURE AND RATE OF HEATING ON THE AUSTENITIC GRAIN SIZE OF 0.5- PERCENT-CARBON STEELS AND IRON-CARBON ALLOY
}

\author{
By Thomas G. Digges and Samuel J. Rosenberg
}

\begin{abstract}
Tests were made to determine the influence of variations in initial structure and rate of heating through the transformation temperature range on the grain sizes at $1,475^{\circ}$ and $1,600^{\circ} \mathrm{F}$ of a high-purity alloy of iron and carbon and two commercial steels each containing 0.5 percent of carbon. Variations in initial structure had no effect on the grain size of the iron-carbon alloy. Although the initial structure had some influence on the grain size of the steels, no correlation was found between the grain size and the spacing of pearlite or the form and distribution of the carbides. The rate of heating had a pronounced effect on the grain size of the iron-carbon alloy, and in some cases the rate of heating also influenced the grain size of the steels. However, the trend in the steels was the reverse of that of the iron-carbon alloy in that the finest grains were obtained in the steels with slow rates of heating.
\end{abstract}

\section{CONTENTS}

Introduction Page

II. Experimental materials and procedure

III. Results_._.

1. Iron-carbon alloy

2. Noncontrolled steel.

3. Controlled steel

IV. Discussion of results

V. Summary

\section{INTRODUCTION}

In a previous study ${ }^{1}$ made with high-purity alloys of iron and carbon and plain carbon steels, it was shown that in certain cases the austenitic grain size was markedly affected by the rate of heating through the transformation temperature range. It was recognized at that time that variation in the initial structure was also a factor that should be considered in a study of austenitic grain size. The work reported herein is concerned with the influence of both the initial structure (i. e., the structure that existed just prior to heating to the temperature establishing the austenitic grain size) and the rate of heating upon the grain size of certain of the materials used in the previous investigation.

\section{EXPERIMENTAL MATERIALS AND PROCEDURE}

The chemical compositions of the alloy and steels used in the present study are given in table 1 . The iron-carbon alloy was prepared in

1 Samuel J. Rosenberg and Thomas G. Digges, Effect of rate of heating through the transformation range on austenitic grain size, J. Research NBS 25, 215 (1940) RP1322; Trans. Am. Soc. Met. 29, 638 (1941). 
the laboratory ${ }^{2}$ and contained less than 0.031 percent of identifiable impurities. The two steels were commercial heats differing principally in the amounts of aluminum oxide and aluminum. Heat designated $C^{-1}$, with the lower proportion of aluminum, was produced under conditions which resulted in noncontrol of austenitic grain size, whereas heat $C-2$ was produced under conditions intended to control the austenitic grain size. Each heat was representative of good commercial practice. In this report, these two steels are occasionally indicated by the terms "noncontrolled grain size" applied to steel $C-1$ and "controlled grain size" applied to steel $C$-2.

The iron-carbon alloy was treated for three different initial structures, which consisted of (a) coarse pearlite, (b) fine pearlite (sorbite), and (c) spheroidized cementite (fig. 1). All of these treatments were carried out in vacuum, and the pearlitic structures were not produced by isothermal reactions.

TABLE 1.-Chemical composition of iron-carbon alloy and steels used

\begin{tabular}{|c|c|c|c|c|c|c|c|c|c|c|c|c|c|}
\hline \multirow[b]{2}{*}{ Identification } & \multicolumn{13}{|c|}{ Element (percentage by weight) } \\
\hline & C & $\mathrm{Mn}$ & $\mathrm{P}$ & $\mathrm{s}$ & $\mathrm{Si}$ & $\mathrm{Ni}$ & Co & $\mathrm{Al}_{2} \mathrm{O}_{3}$ & $\begin{array}{c}\text { Acid } \\
\text { solu- } \\
\text { ble } \\
\text { Al }\end{array}$ & $\begin{array}{c}\text { Total } \\
\text { Al }\end{array}$ & ${ }^{1} \mathrm{H}_{2}$ & $\mathrm{O}_{2}$ & $\mathrm{~N}_{2}$ \\
\hline $\begin{array}{l}\text { Iron-carbon alloy }{ }^{2} \\
\text { Noncontrolled steel } \\
(C-1) \\
\text { Controlled steel }(C-2)\end{array}$ & $\begin{array}{r}0.50 \\
.49 \\
.49\end{array}$ & $\begin{array}{r}0.002 \\
.79 \\
.80\end{array}$ & $\begin{array}{r}<0.001 \\
.023 \\
.022\end{array}$ & $\begin{array}{r}0.004 \\
.023 \\
.028\end{array}$ & $\begin{array}{r}0.002 \\
.22 \\
.21\end{array}$ & \begin{tabular}{c}
0.007 \\
\hdashline \\
\hdashline-
\end{tabular} & 0.007 & $\begin{array}{r}3 \mathrm{ND} \\
.001 \\
.007\end{array}$ & $\begin{array}{l}\mathrm{ND} \\
.002 \\
.016\end{array}$ & $\begin{array}{l}\text { ND } \\
.0025 \\
.0195\end{array}$ & $\begin{array}{l}0.0002 \\
.0002 \\
.0002\end{array}$ & $\begin{array}{r}0.003 \\
.004 \\
.003\end{array}$ & $\begin{array}{r}0.001 \\
4.004 \\
.004\end{array}$ \\
\hline
\end{tabular}

1 Values for gaseous elements obtained by the vacuum-fusion method.

2 Total identifiable impurities, less than 0.031 percent, obtained by spectrochemical, chemical, and vacuum-fusion analyses.

3 ND means not detected.

Each of the two commercial steels was treated to give initial structures differing in the interlamellar spacing of pearlite or in the form and distribution of the carbides (figs. 2 and 3). These initial structures were (a) coarse pearlite obtained by pack-annealing at $1,700^{\circ} \mathrm{F}$; (b) medium pearlite obtained by air-cooling after hot-rolling; (c) fine pearlite (sorbite) formed by isothermal reaction at about $1,010^{\circ} \mathrm{F}$; (d) bainite formed by isothermal reaction at $720^{\circ}$ to $750^{\circ} \mathrm{F}$; and (e) spheroidized cementite produced by prolonged heating of sorbitized steel in the temperature range of $1,200^{\circ}$ to $1,300^{\circ} \mathrm{F}$.

An interesting feature of the spheroidized structure of the ironcarbon alloy was the tendency of the carbides to coalesce in the form of a network, as is shown in figure 1, C.

The experimental procedure used was the same as that described in detail in the previous report (see footnote 1). Essentially, it consisted in heating small specimens, approximately $1 / 10$ inch square by 0.04 inch thick, in a lead bath or in vacuum at various rates to $1,475^{\circ}$ or $1,600^{\circ} \mathrm{F}$. The specimens were held at these temperatures for 15 minutes and then cooled in a manner suitable for delineating the austenite grains with proeutectoid ferrite.

For the fastest rates of heating, the specimens were plunged into a lead bath maintained at a temperature of either $1,475^{\circ}$ or $1,600^{\circ} \mathrm{F}$.

${ }^{2}$ Thomas G. Digges, Effect of carbon on critical cooling rate of high-purity iron-carbon alloys and plain carbon steels, J. Research NBS 20, 571 (1938) RP1092; also, Effect of carbon on the hardenability of high-purity ironcarbon alloys, Trans. Am. Soc. Metals 26, 408 (1938). 
For the specimens heated in vacuum, the rates of heating through the transformation range were taken as the average rates required to heat through the temperature range from $1,325^{\circ}$ to $1,450^{\circ} \mathrm{F}$. Two or more specimens were frequently used for any selected condition of test. The average grain sizes obtained are shown by representative micrographs at 100 diameters in figures 4 to 29 , and the estimated American Society for Testing Materials grain numbers are summarized in table 2. This table is included as an aid in comparing the effect of the variables studied. The grain-size numbers enumerated were obtained by estimation on larger micrographs than are shown in the figures. It is not always possible to show small differences in grain size by numbers; comparison of micrographs conveys a more definite picture. This is particularly true where the grain sizes are small (compare, for instance, figs. $21, D$, and $22, D$, both of which were rated as grain No. 8). 
TABLE 2.-Influence of initial structure and rate of heating on austenitic grain size

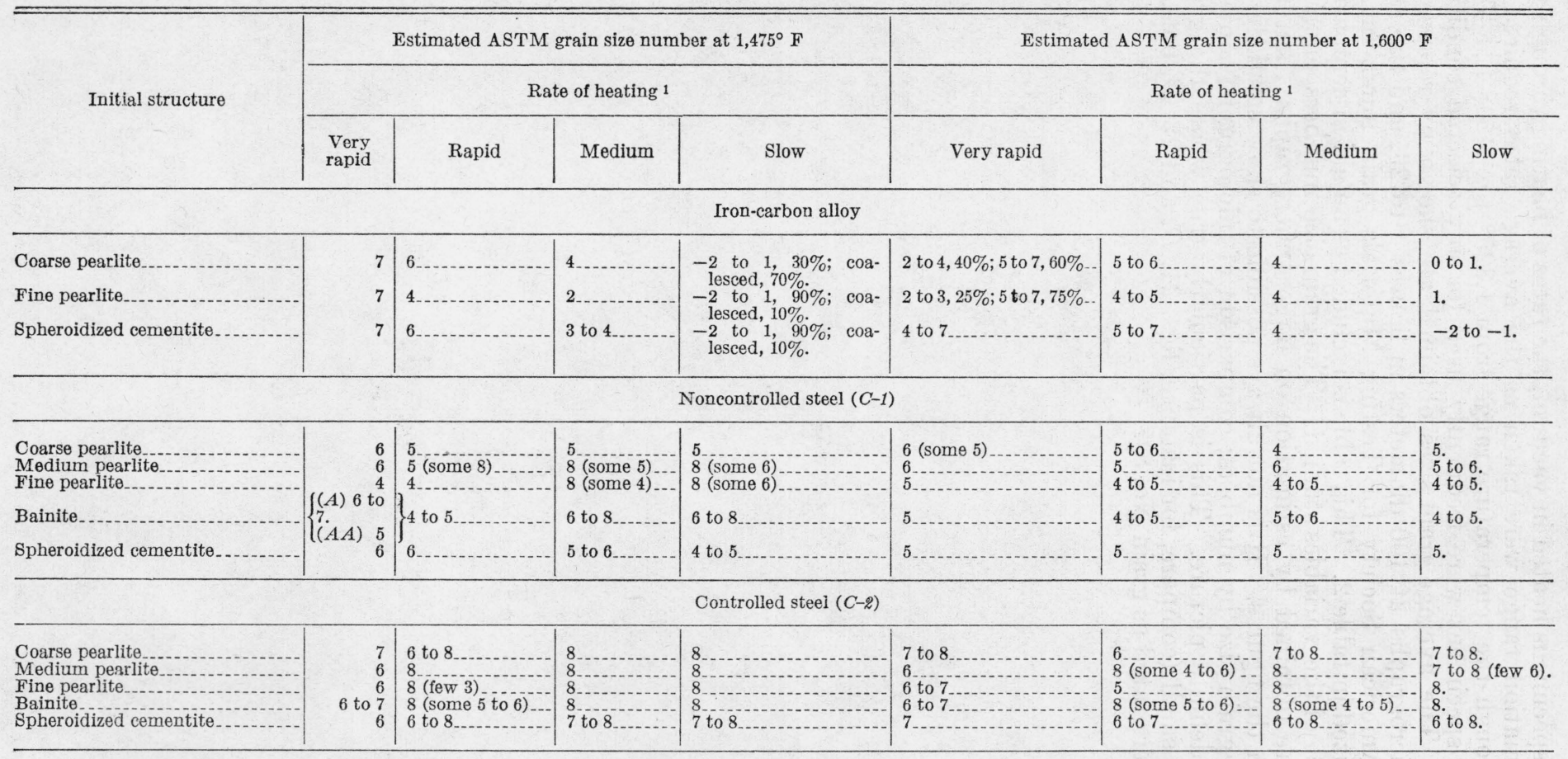

1 The rate of heating was not a constant for each condition listed. Values for some of the rates used are summarized in figures 4 to 29 . 

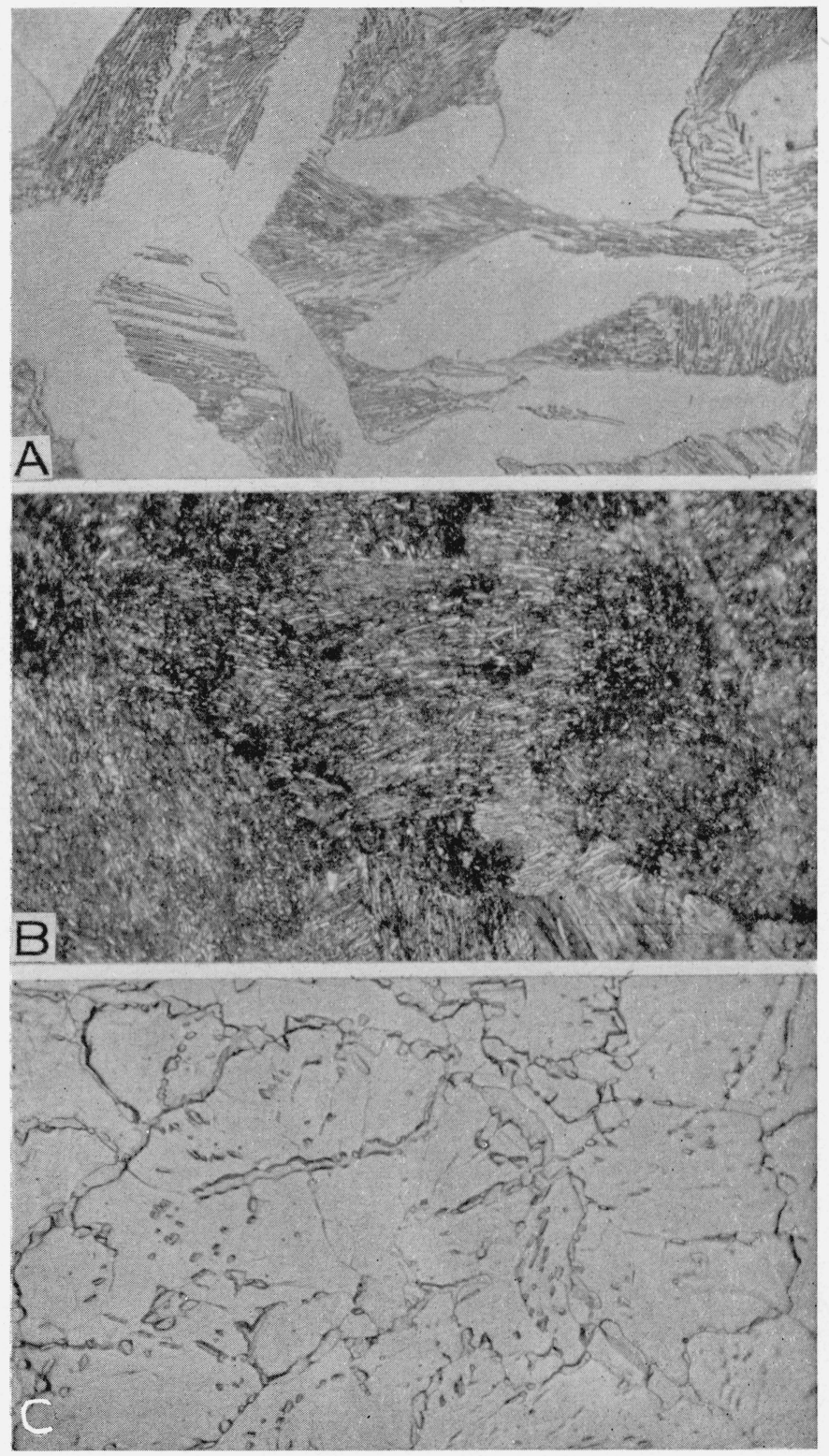

Figure 1.-Initial structures of the iron-carbon alloy.

$A$, coarse pearlite; $B$, fine pearlite; $C$, spheroidized cementite. Etched with 1-percent nital, $\times 500$. 

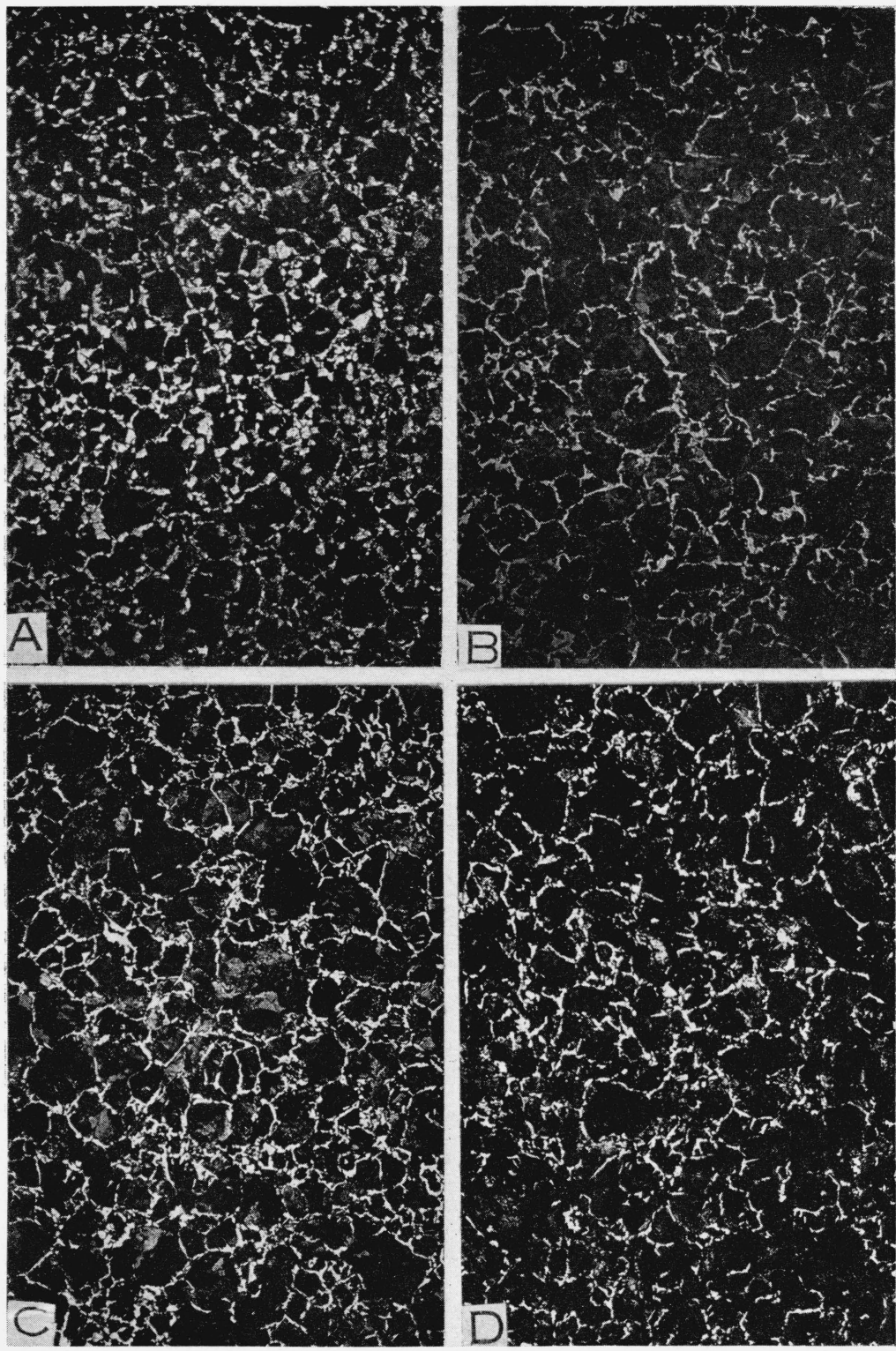

Figure 10.-Austenitic grain size at $1,475^{\circ} \mathrm{F}$ of noncontrolled steel $\mathrm{C}-1$ with initial structure of coarse pearlite.

$A$, heated in lead bath; $B$, heated at $1,070^{\circ} \mathrm{F} / \mathrm{min} ; C$, heated at $120^{\circ} \mathrm{F} / \mathrm{min} ; D$, heated at $6^{\circ} \mathrm{F} / \mathrm{min}$. Etched with 1-percent nital, $\times 100$. 

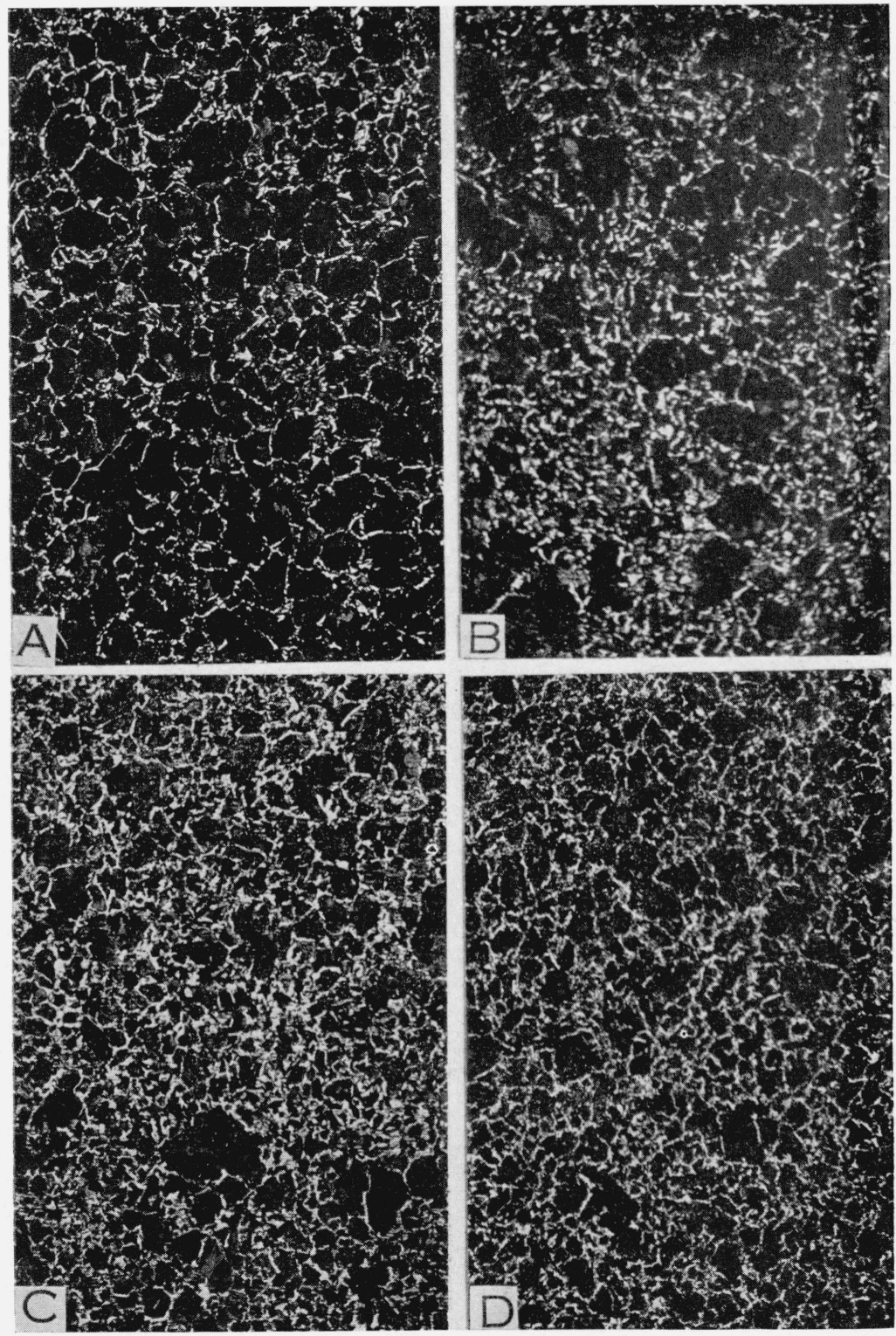

Figure 11.-Austenitic grain size at $1,475^{\circ} \mathrm{F}$ of noncontrolled steel $C-1$ with initial structure of medium pearlite.

1. Theated in lead bath; $B$, heated at $830^{\circ} \mathrm{F} / \mathrm{min} ; C$, heated at $180^{\circ} \mathrm{F} / \mathrm{min} ; D$, heated at $4^{\circ} \mathrm{F} / \mathrm{min}$. Etched with 1-percent nital, $\times 100$. 

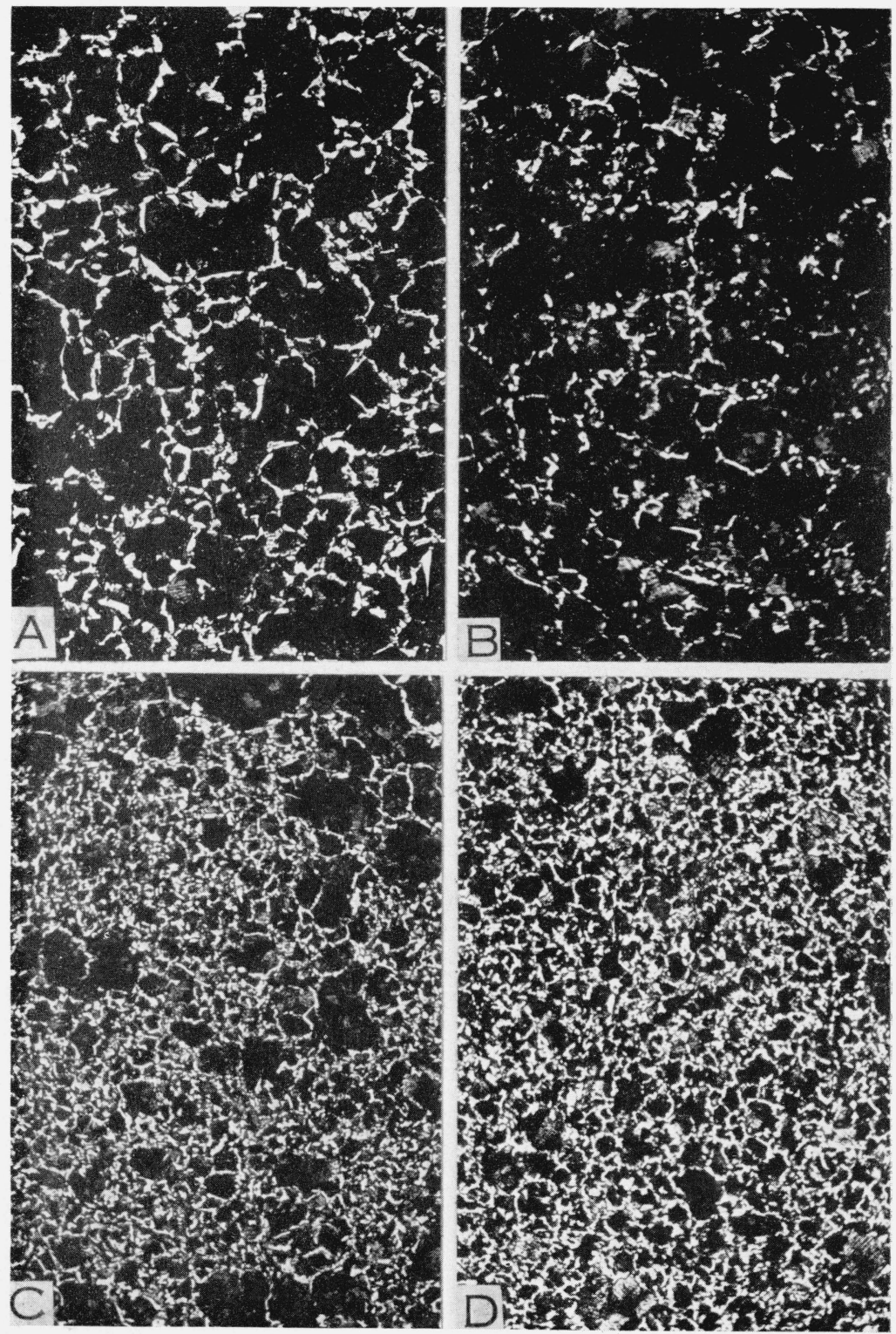

Figure 12.-Austenitic grain size at $1,475^{\circ} \mathrm{F}$ of noncontrolled steel $\mathrm{C}-1$ with initial structure of fine pearlite.

$A$, heated in lead bath; $B$, heated at $680^{\circ} \mathrm{F} / \mathrm{min} ; C$, heated at $160^{\circ} \mathrm{F} / \mathrm{min} ; D$, heated at $6^{\circ} \mathrm{F} / \mathrm{min}$. Etched with 1-percent nital, $\times 100$ 


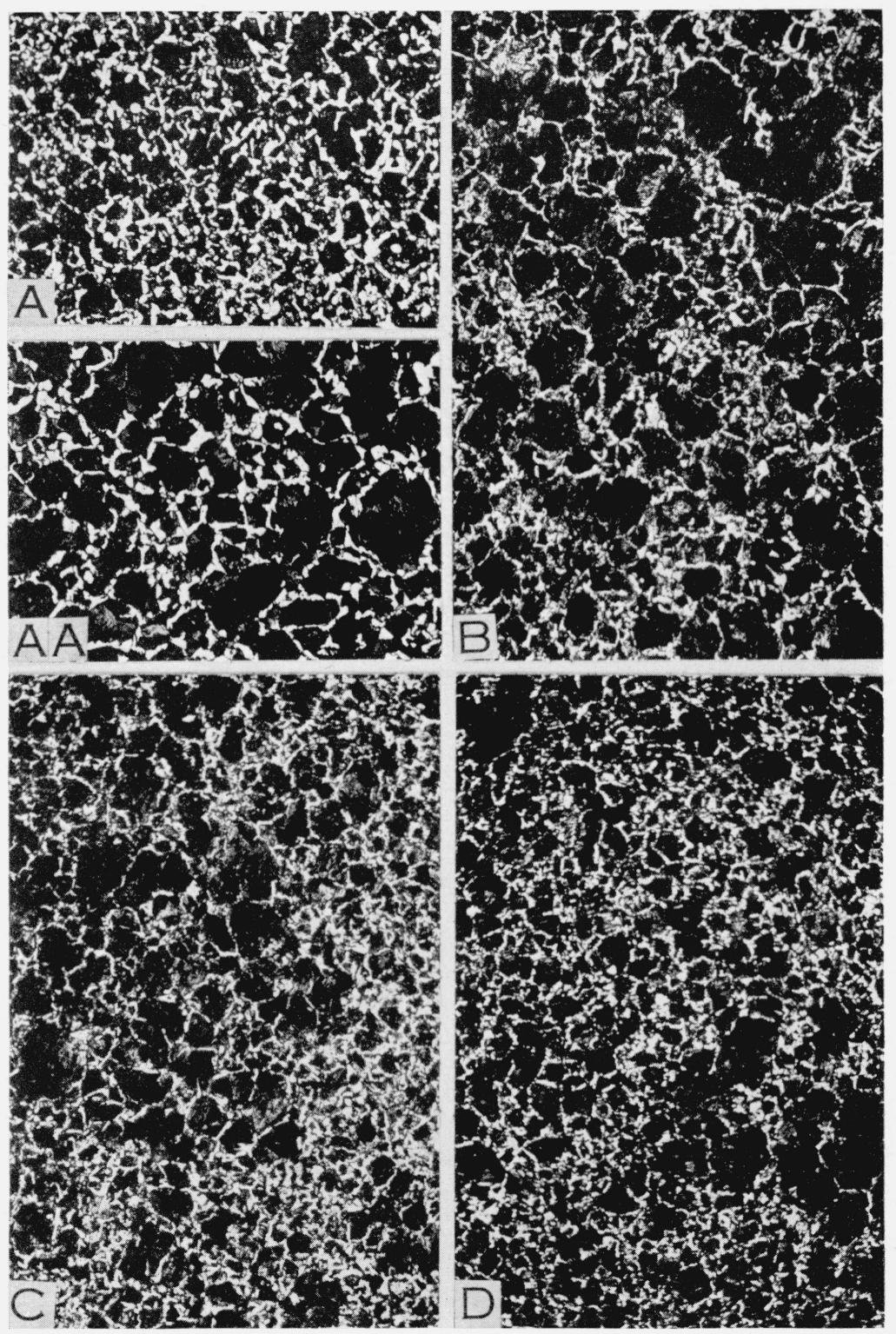

FIGURE 13.-Austenitic grain size at $1,475^{\circ} \mathrm{F}$ of noncontrolled steel $\mathrm{C}-1$ with initial structure of bainite.

$A$ and $A A$, heated in lead bath; $B$, heated at $570^{\circ} \mathrm{F} / \mathrm{min} ; C$, heated at $110^{\circ} \mathrm{F} / \mathrm{min} ; D$, heated at $6^{\circ} \mathrm{F} / \mathrm{min}$. Etched with 1-percent nital, $\times 100$. 

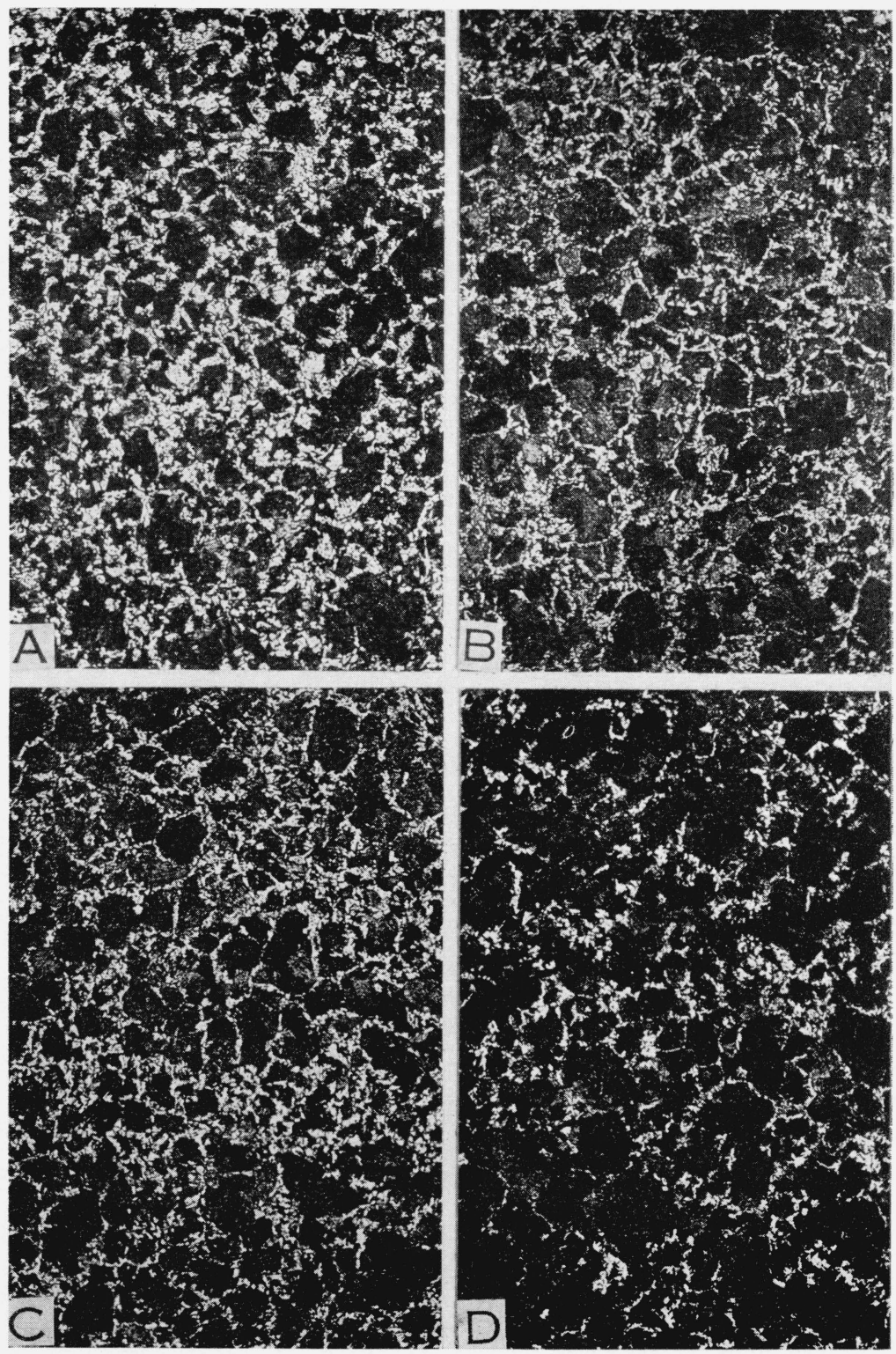

FigURE 14.-Austenitic grain size at $1,475^{\circ} \mathrm{F}$ of noncontrolled steel $C-1$ with initial structure of spheroidized cementite.

$A$, heated in lead bath; $B$, heated at $940^{\circ} \mathrm{F} / \mathrm{min} ; C$, heated at $80^{\circ} \mathrm{F} / \mathrm{min} ; D$, heated at $5^{\circ} \mathrm{F} / \mathrm{min}$. Etched with 1-percent nital, $\times 100$. 

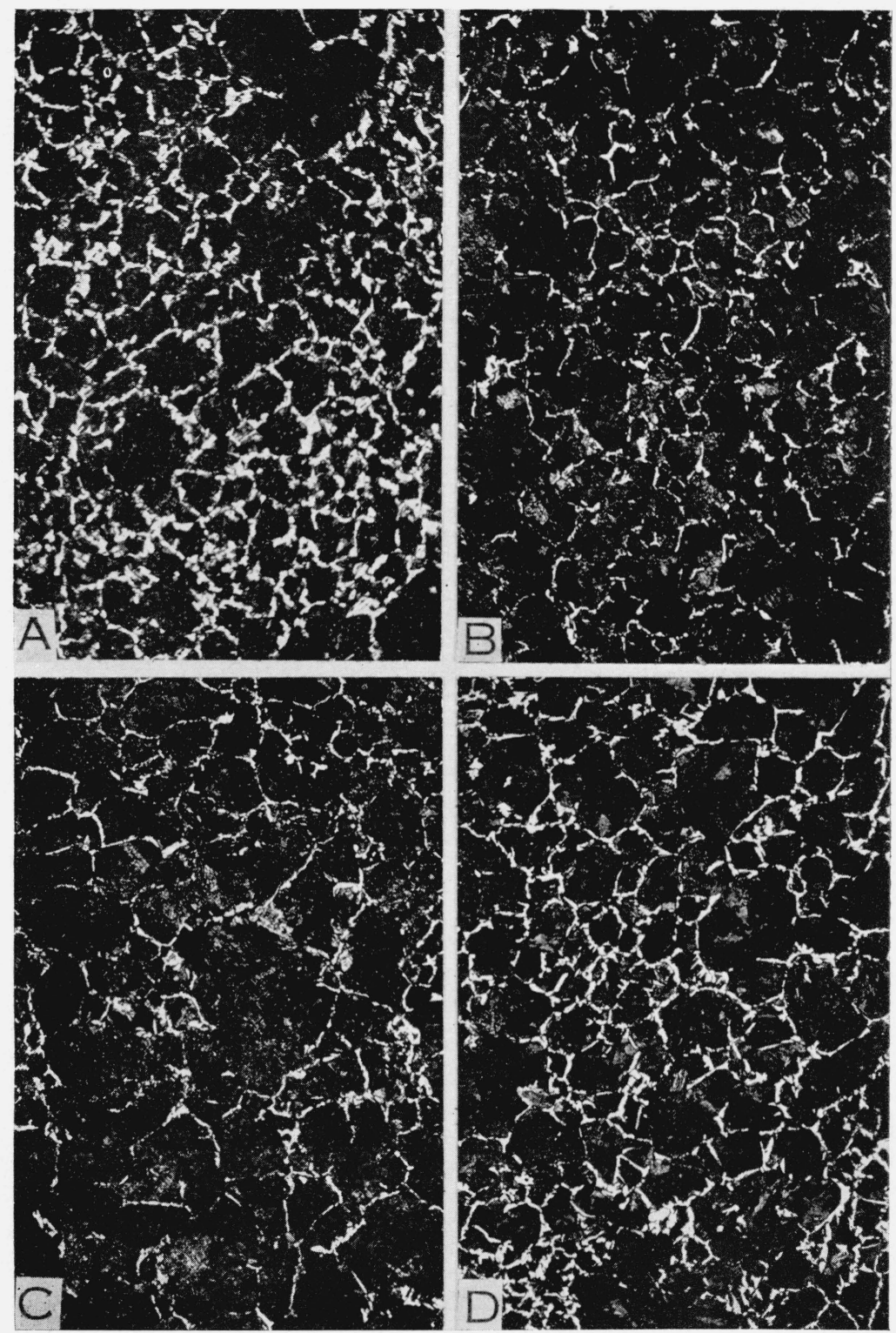

FIGURE 15.-Austenitic grain size at $1,600^{\circ} \mathrm{F}$ of noncontrolled steel $\mathrm{C}-1$ with initial structure of coarse pearlite.

$A$, heated in lead bath; $B$, heated at $1,320^{\circ} \mathrm{F} / \mathrm{min} ; C$, heated at $110^{\circ} \mathrm{F} / \mathrm{min} ; D$, heated at $5^{\circ} \mathrm{F} / \mathrm{min}$. Etched with 1-percent nital, $\times 100$. 

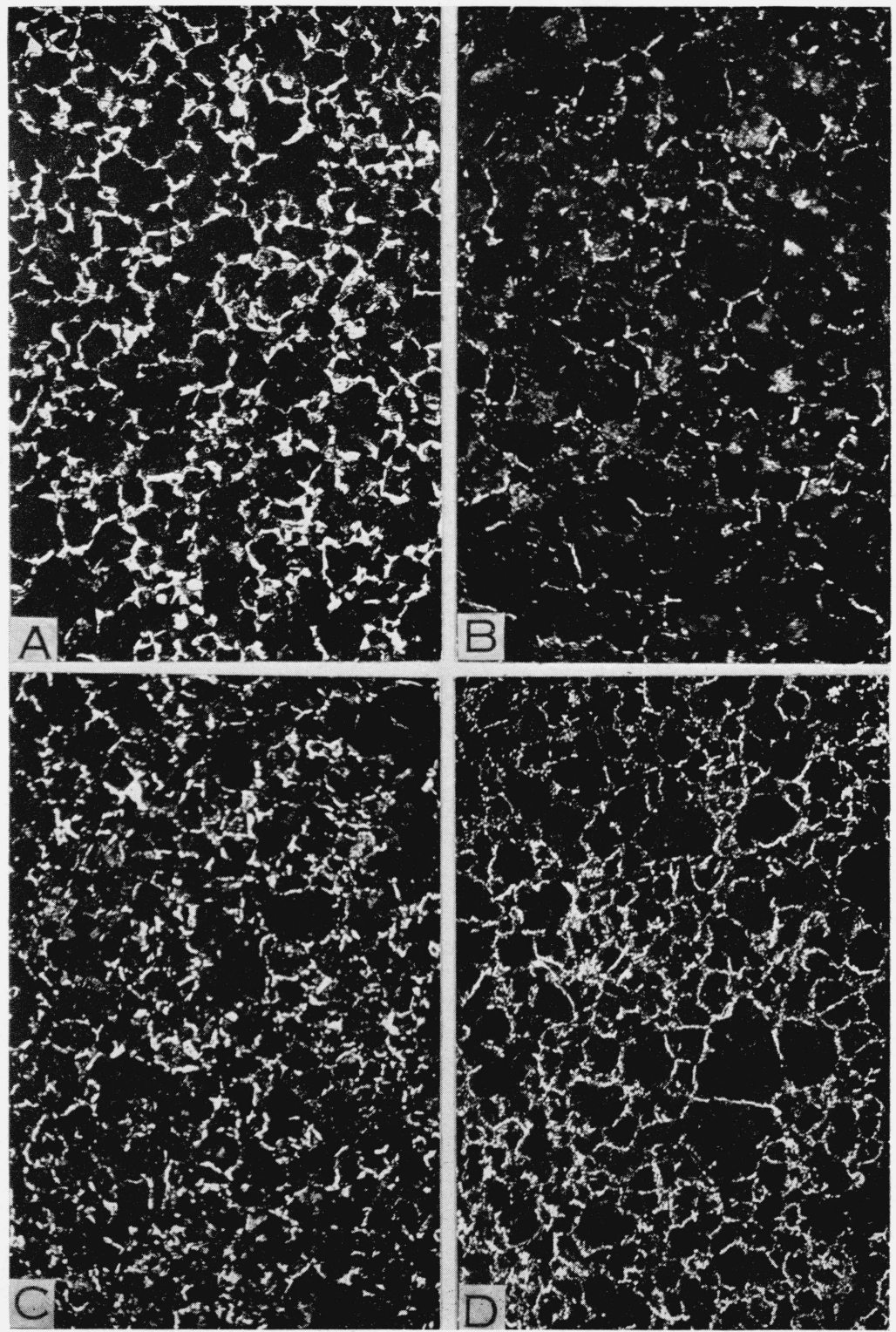

FIGURE 16.-Austenitic grain size at $1,600^{\circ} \mathrm{F}$ of noncontrolled steel $\mathrm{C}-1$ with initial structure of medium pearlite.

$A$, heated in lead bath; $B$, heated at $1,070^{\circ} \mathrm{F} / \mathrm{min} ; C$, heated at $110^{\circ} \mathrm{F} / \min ; D$, heated at $4^{\circ} \mathrm{F} / \mathrm{min}$. Etched with 1-percent nital, $\times 100$ 


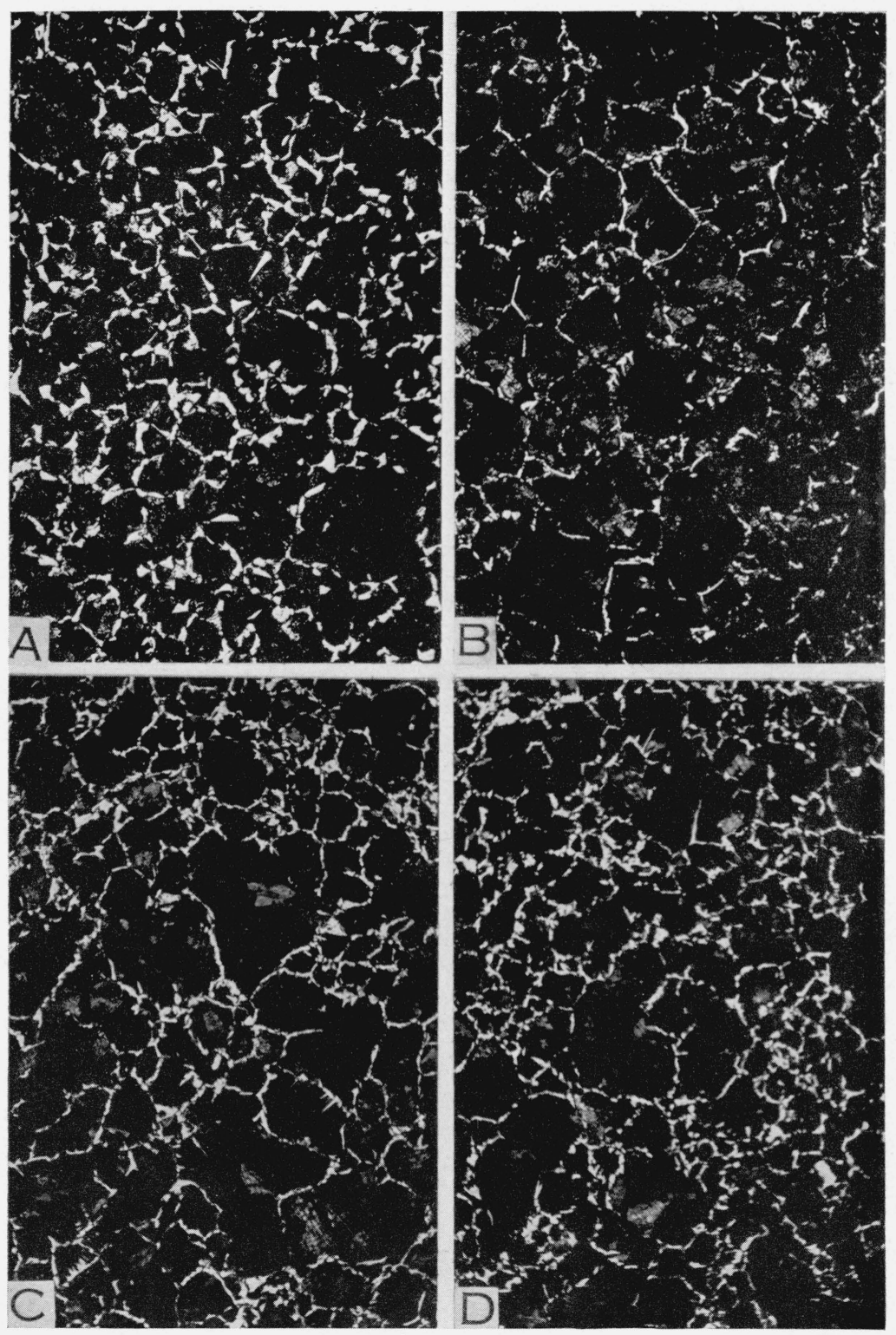

FiguRe 17.-Austenitic grain size at $1,600^{\circ} \mathrm{F}$ of noncontrolled steel $\mathrm{C}-1$ with initial structure of fine pearlite.

$A$, heated in lead bath; $B$, heated at $940^{\circ} \mathrm{F} / \mathrm{min} ; C$, heated at $90^{\circ} \mathrm{F} / \mathrm{min} ; D$, heated at $5^{\circ} \mathrm{F} / \mathrm{min}$. Etched with 1-percent nital, $\times 100$. 

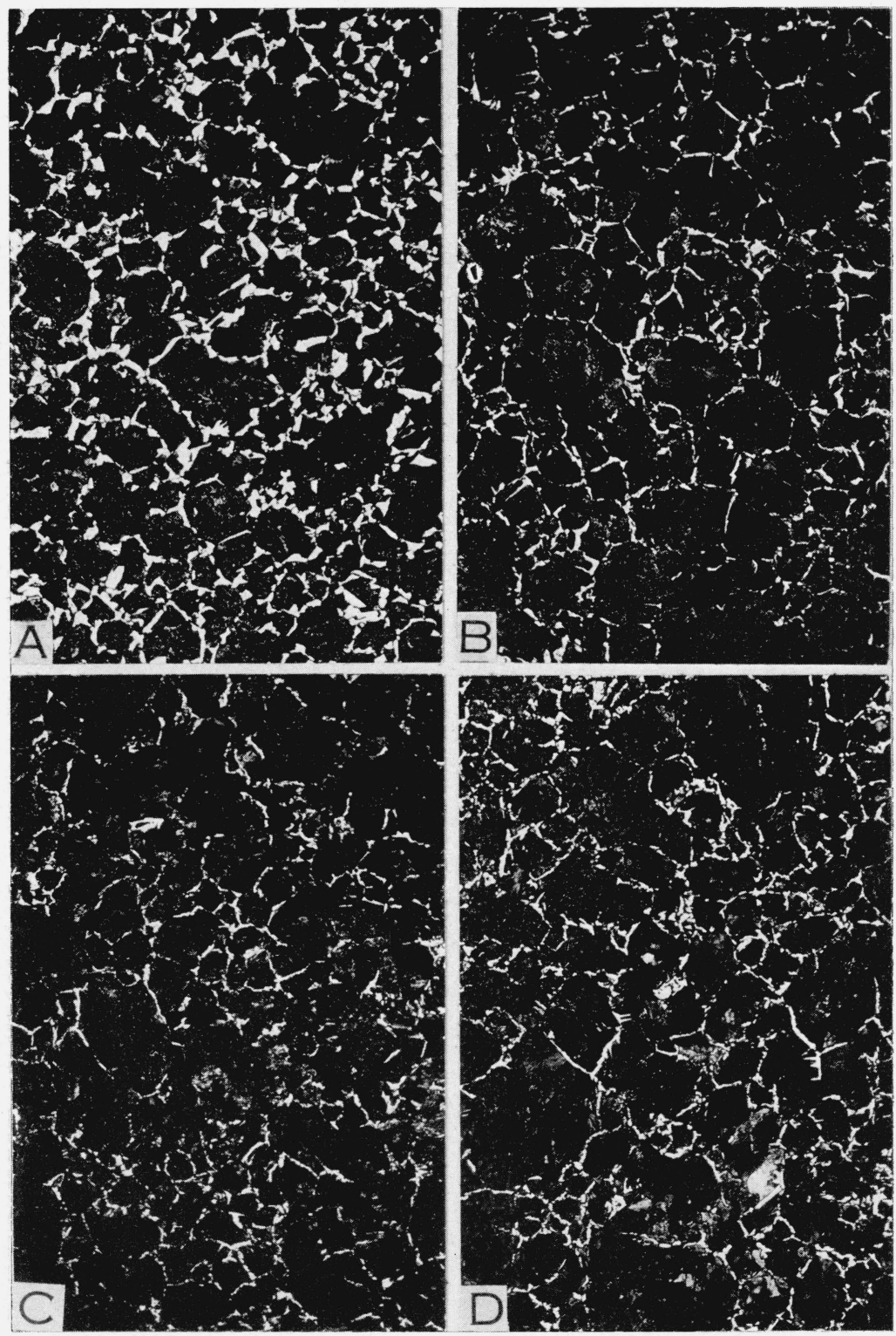

FIGURE 18.-Austenitic grain size at $1,600^{\circ} \mathrm{F}$ of noncontrolled steel $\mathrm{C}-1$ with initial structure of bainite.

$A$, heated in lead bath; $B$, heated at $830^{\circ} \mathrm{F} / \mathrm{min} ; C$, heated at $280^{\circ} \mathrm{F} / \mathrm{min} ; D$, heated at $9^{\circ} \mathrm{F} / \mathrm{min}$. Etched with 1-percent nital, $\times 100$. 

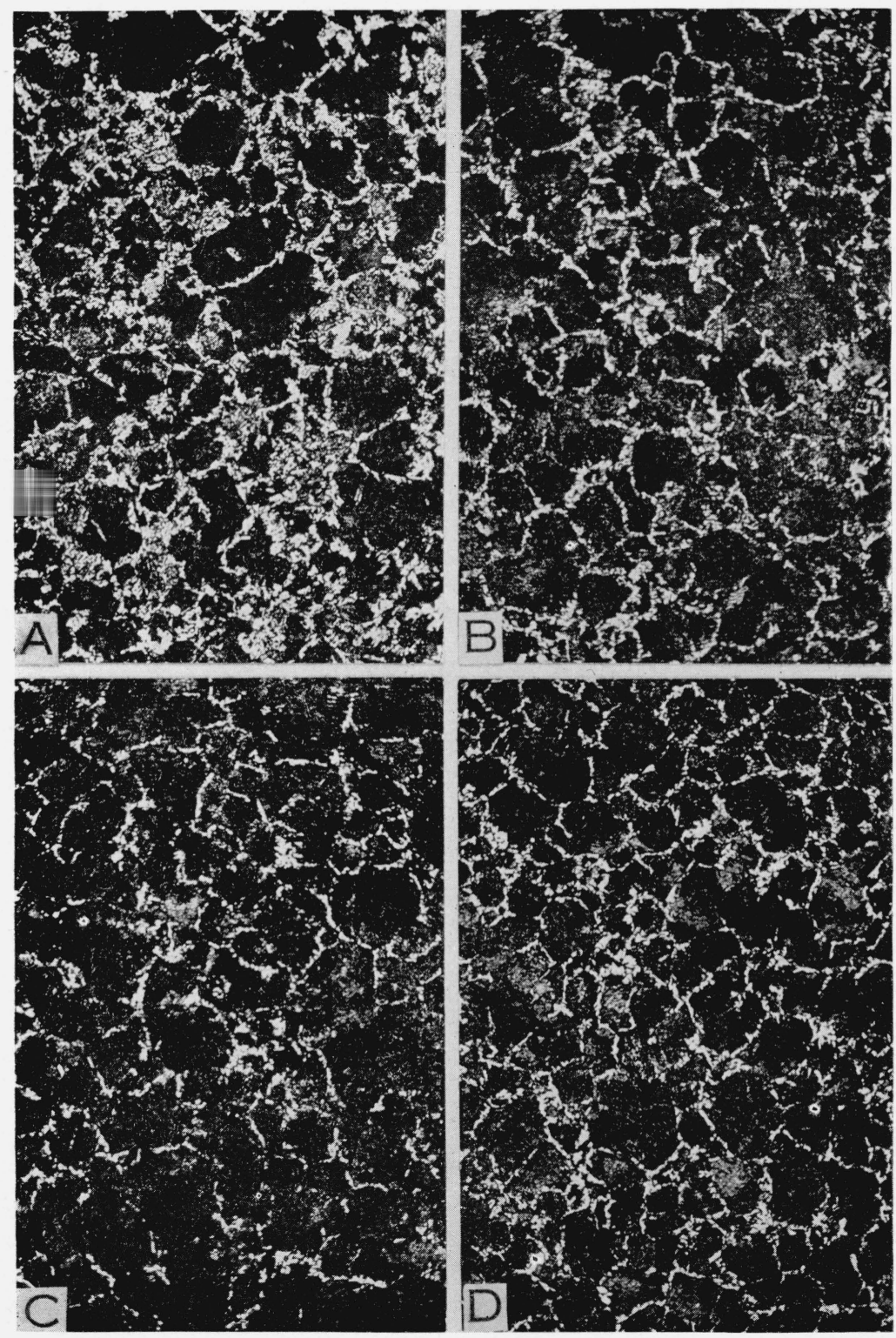

FiguRE 19.-Austenitic grain size at $1,600^{\circ} \mathrm{F}$ of noncontrolled steel $\mathrm{C}-1$ with initial structure of spheroidized cementite.

$A$, heated in lead bath: $B$, heated at $750^{\circ} \mathrm{F} / \mathrm{min} ; C$, heated at $20^{\circ} \mathrm{F} / \mathrm{min} ; D$, heated at $7^{\circ} \mathrm{F} / \mathrm{min}$. Etched with 1-percent nital, $\times 100$. 

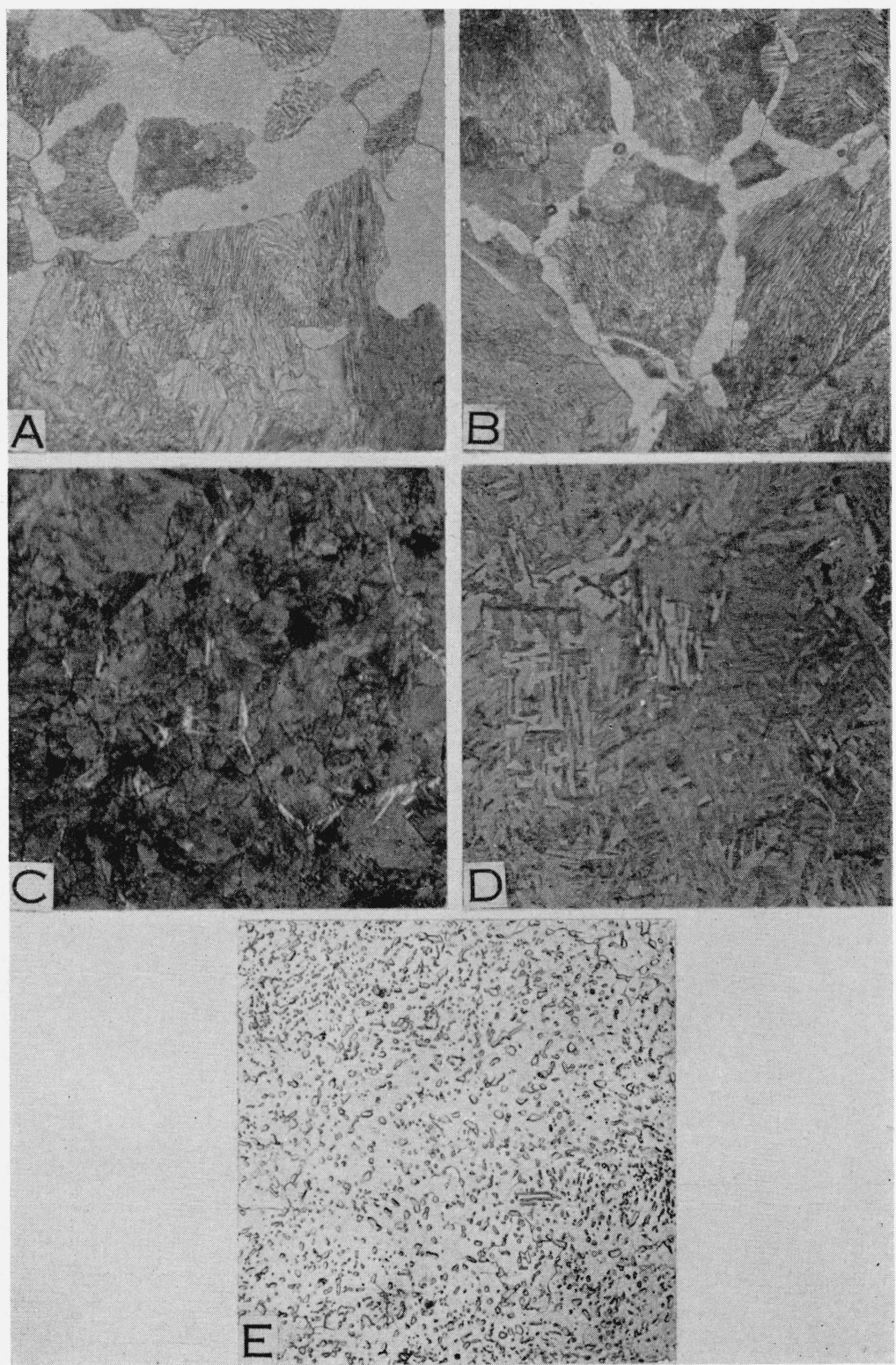

Figure 2.-Initial structures of noncontrolled steel $C-1$.

$A$, coarse pearlite; $B$, medium pearlite; $C$, fine pearlite; $D$, bainite; $E$, spheroidized cementite. Etched with 1 -percent nital, $\times 500$. 

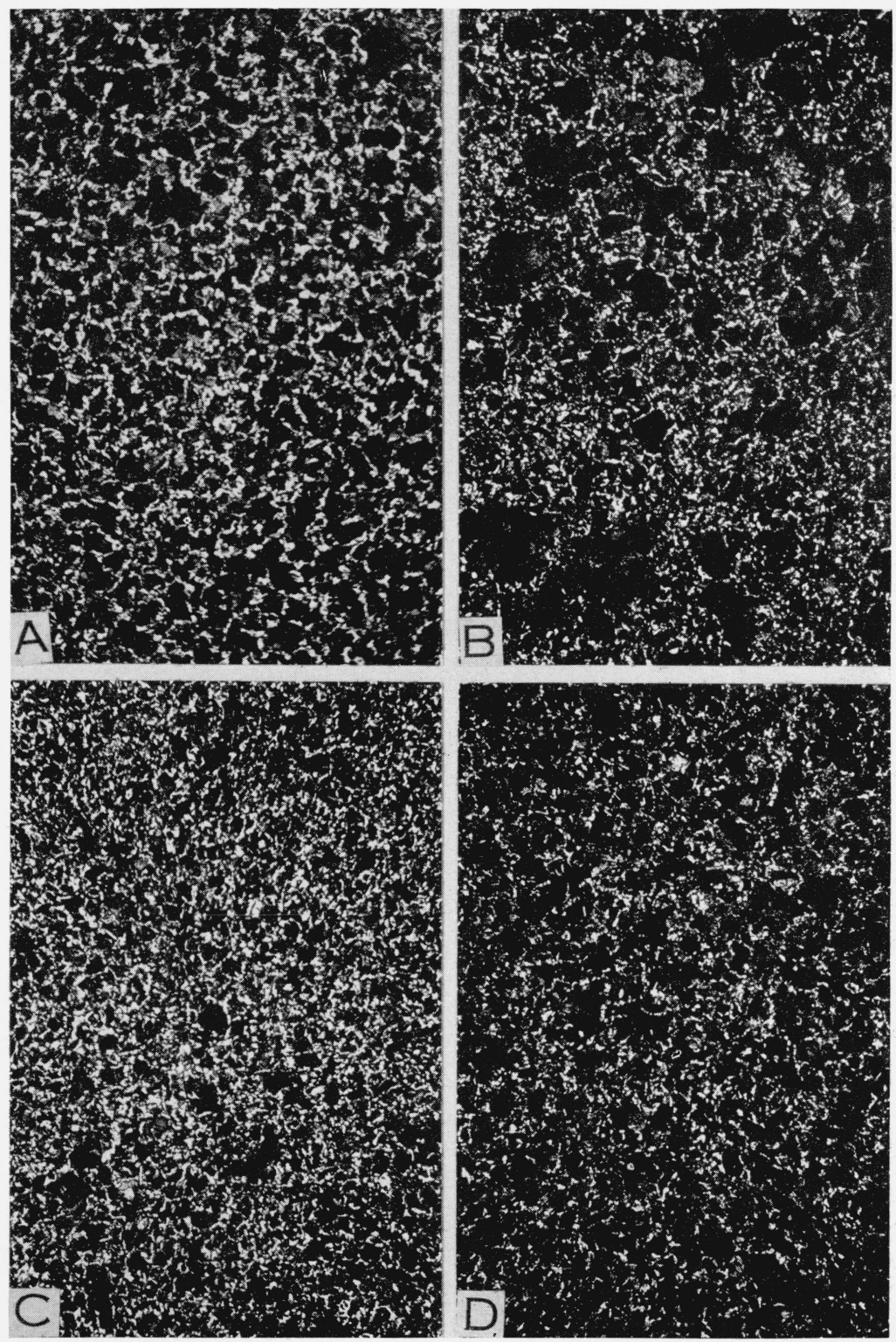

FIGURE 20.-Austenitic grain size at $1,475^{\circ} \mathrm{F}$ of controlled steel $\mathrm{C}-2$ with initial structure of coarse pearlite.

$A$, heated in lead bath; $B$, heated at $750^{\circ} \mathrm{F} / \mathrm{min} ; C$, heated at $110^{\circ} \mathrm{F} / \mathrm{min} ; D$, heated at $3^{\circ} \mathrm{F} / \mathrm{min}$. Etched with 1-percent nital, $\times 100$. 

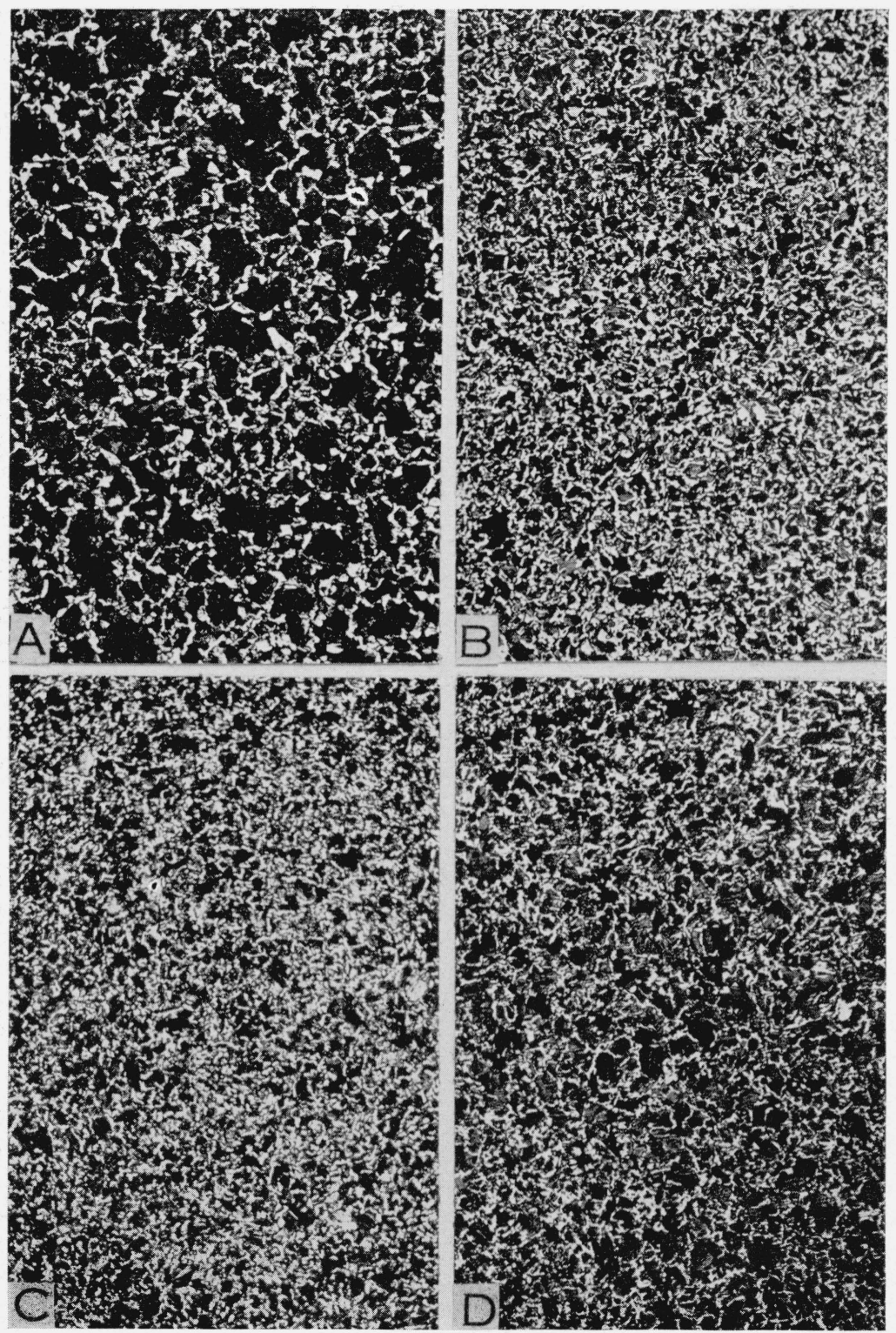

Figure 21.-Austenitic grain size at $1,475^{\circ} \mathrm{F}$ of controlled steel $\mathrm{C}-2$ with initial structure of medium pearlite.

$A$, heated in lead bath; $B$, heated at $420^{\circ} \mathrm{F} / \mathrm{min} ; G$, heated at $120^{\circ} \mathrm{F} / \mathrm{min} ; D$, heated at $3^{\circ} \mathrm{F} / \mathrm{min}$. Etched with 1-percent nital, $\times 100$ 

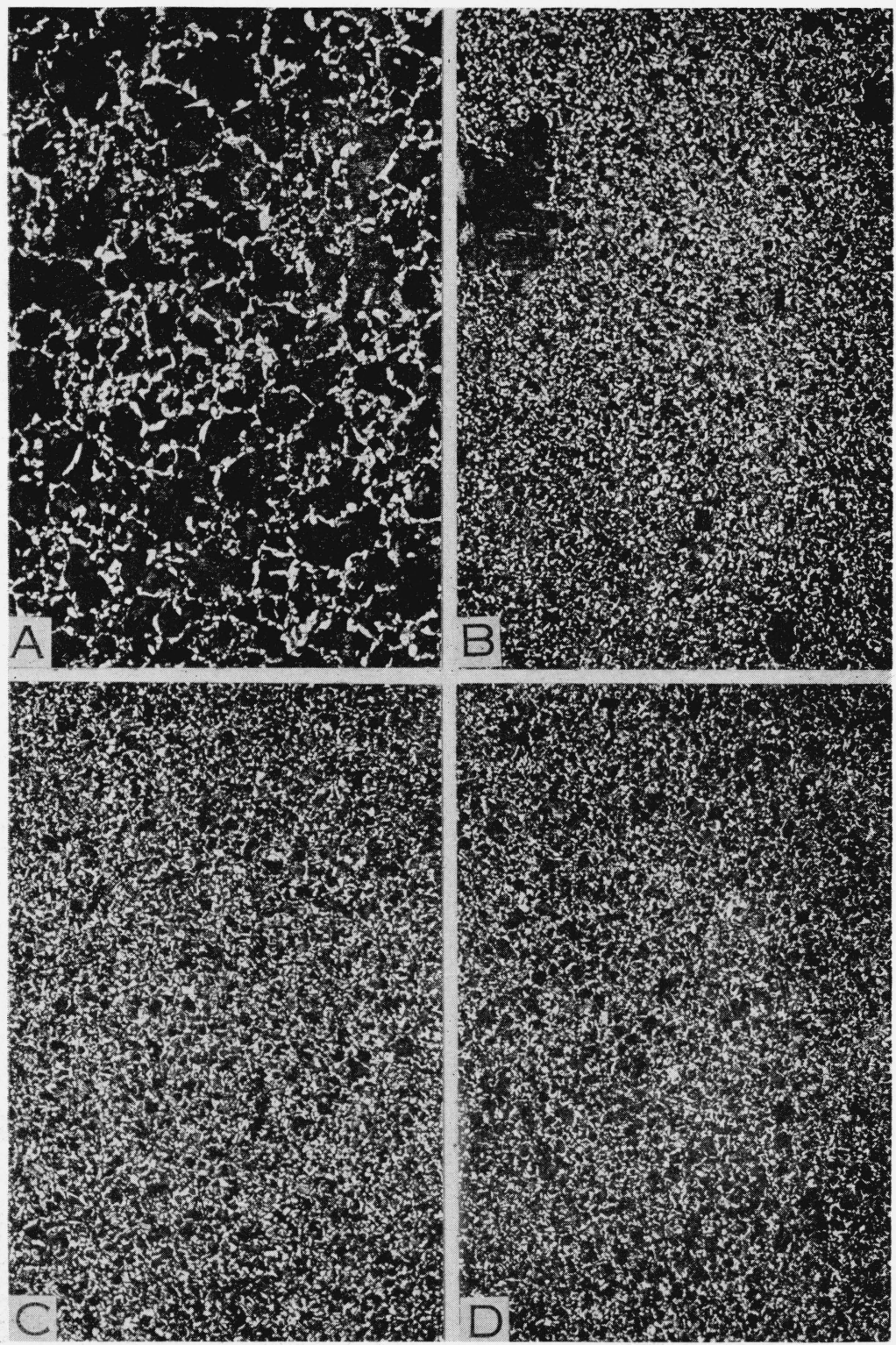

FigURE 22.-Austenitic grain size at $1,475^{\circ} \mathrm{F}$ of controlled steel $\mathrm{C}-2$ with initial structure of fine pearlite.

$A$, heated in lead bath; $B$, heated at $750^{\circ} \mathrm{F} / \mathrm{min} ; C$, heated at $130^{\circ} \mathrm{F} / \mathrm{min} ; D$, heate 1 at $4^{\circ} \mathrm{F} / \mathrm{min}$. Etched with 1-percent nital, $\times 100$ 

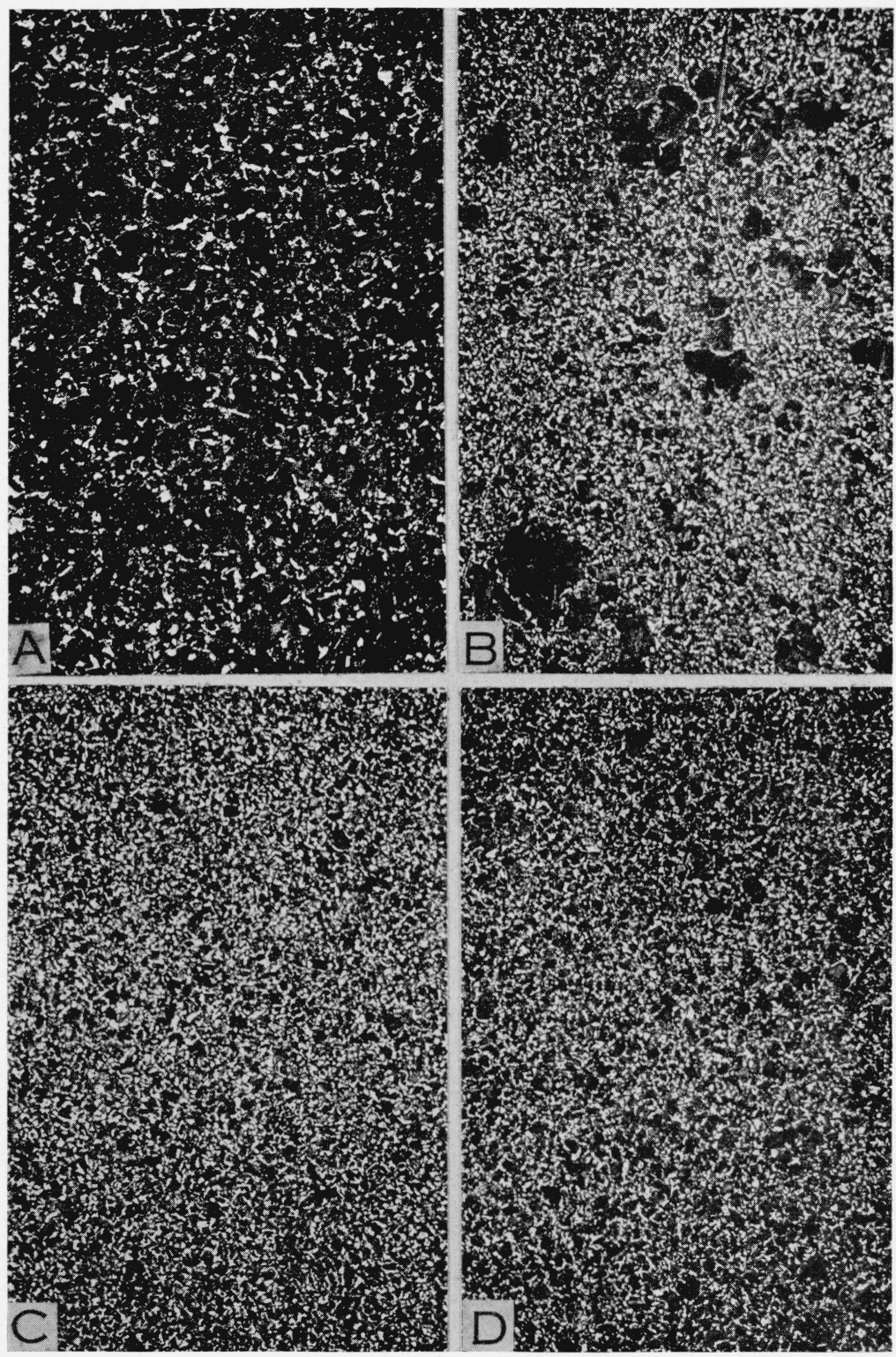

Figure 23.-Austenitic grain size at $1,475^{\circ} \mathrm{F}$ of controlled steel $\mathrm{C}-2$ with initial structure of bainite.

$A$, heated in lead bath; $B$, heated at $680^{\circ} \mathrm{F} / \mathrm{min} ; C$, heated at $130^{\circ} \mathrm{F} / \mathrm{min} ; D$, heated at $4^{\circ} \mathrm{F} / \mathrm{min}$. Etched with 1-percent nital, $\times 100$. 

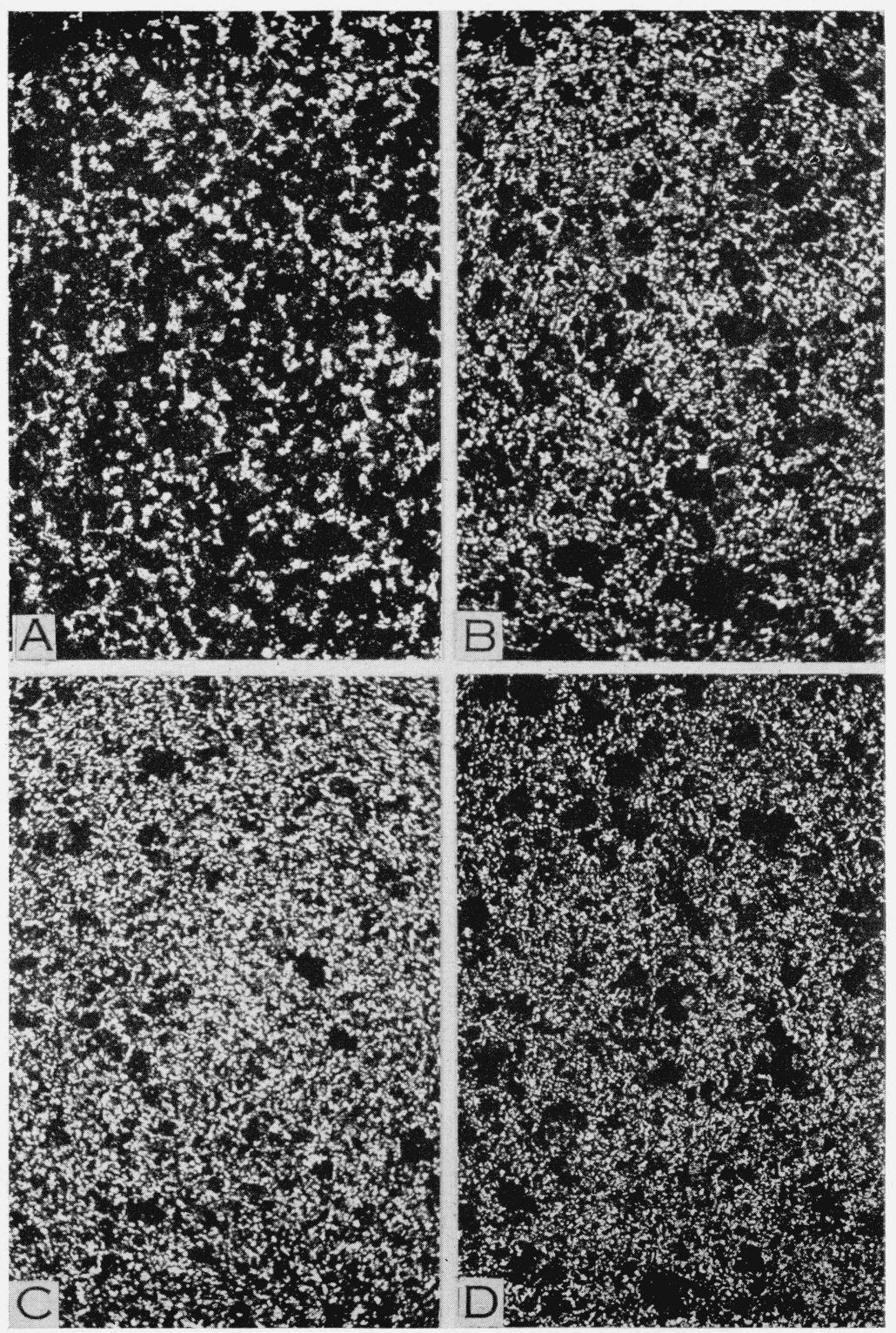

Figure 24.-Austenitic grain size at $1,475^{\circ} \mathrm{F}$ of controlled steel $\mathrm{C}-2$ with initial structure of spheroidized cementite.

$A$, heated in lead bath; $B$, heated at $1,080^{\circ} \mathrm{F} / \mathrm{min} ; C$, heated at $90^{\circ} \mathrm{F} / \mathrm{min} ; D$, heated at $4^{\circ} \mathrm{F} / \mathrm{min}$. Etched with 1-percent nital, $\times 100$ 

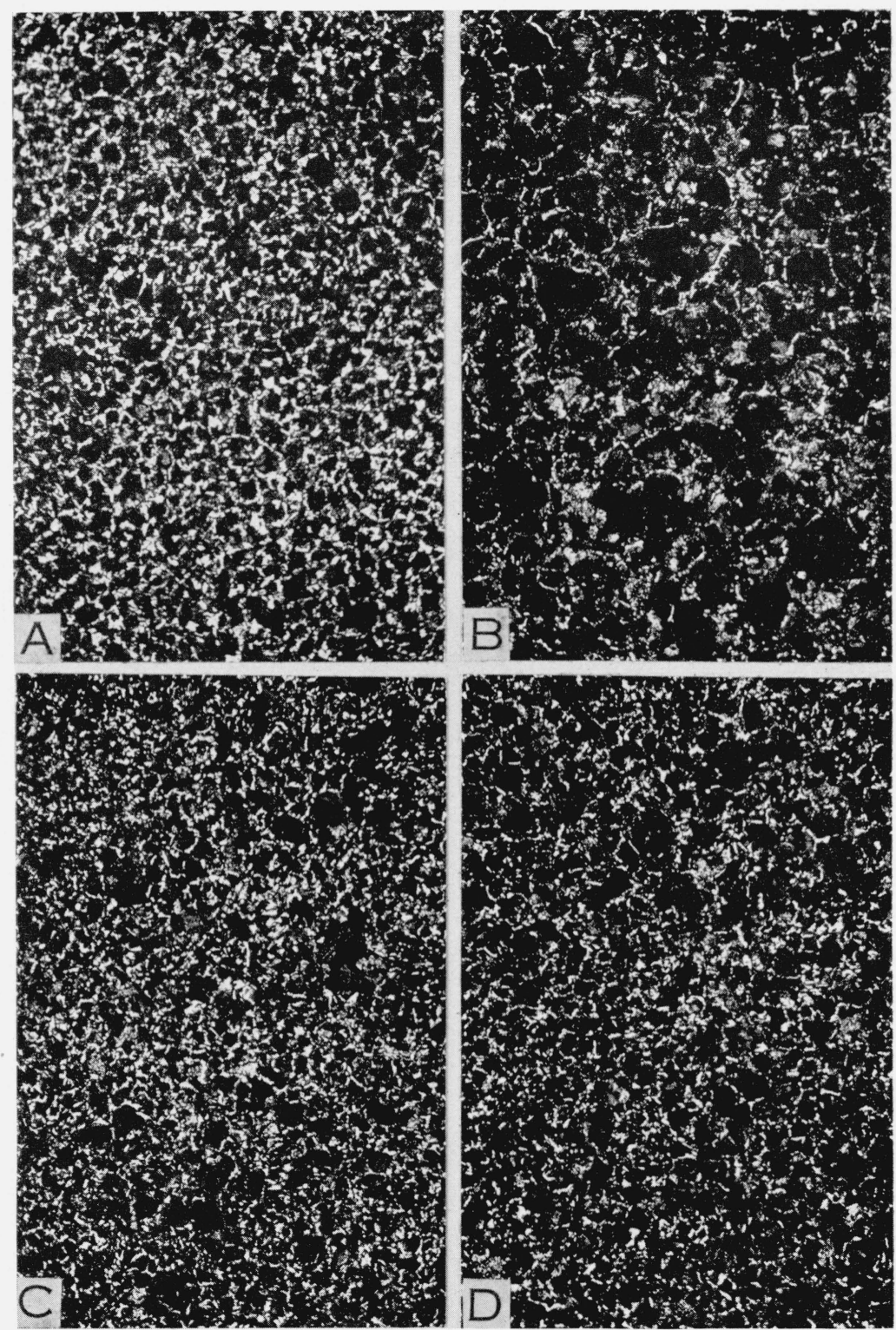

Figure 25.-Austenitic grain size at $1,600^{\circ} \mathrm{F}$ of controlled steel $\mathrm{C}-2$ with initial structure of coarse pearlite.

$A$, heated in lead bath; $B$, heated at $1,250^{\circ} \mathrm{F} / \mathrm{min} ; C$, heated at $140^{\circ} \mathrm{F} / \mathrm{min} ; D$, heated at $7^{\circ} \mathrm{F} / \mathrm{min}$. Etched with 1-percent nital, $\times 100$. 

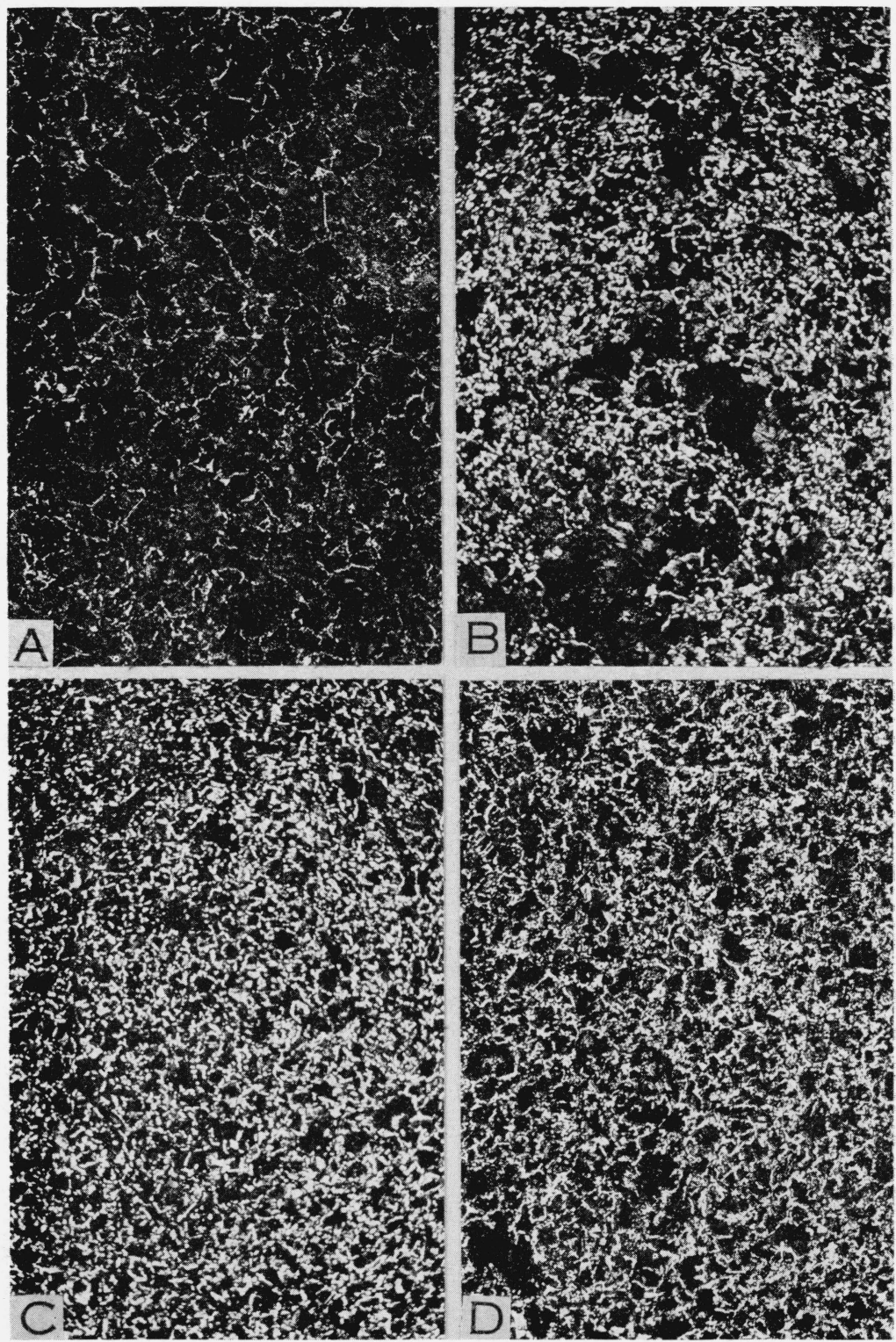

Figure 26.-Austenitic grain size at $1,600^{\circ} \mathrm{F}$ of controlled steel $\mathrm{C}-2$ with initial structure of medium pearlite.

$A$, heated in lead bath; $B$, heated at $1,500^{\circ} \mathrm{F} / \mathrm{min} ; C$, heated at $100^{\circ} \mathrm{F} / \mathrm{min} ; D$, heated at $3^{\circ} \mathrm{F} / \mathrm{min}$. Etched with 1-percent nital, $\times 100$. 

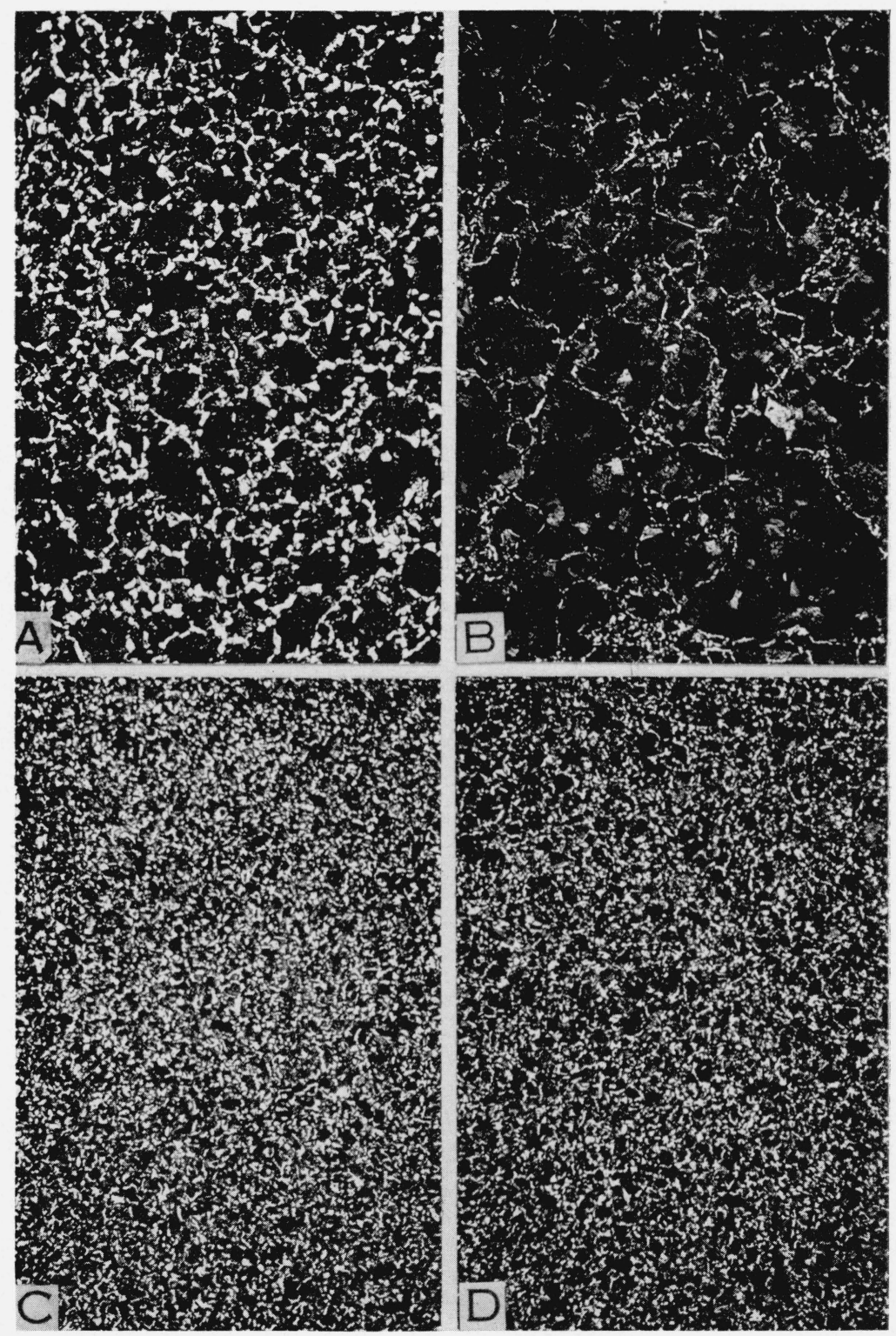

Figure 27.-Austenitic grain size at $1,600^{\circ} \mathrm{F}$ of controlled steel $\mathrm{C}-2$ with initial structure of fine pearlite.

$A$, heated in lead bath; $B$, heated at $940^{\circ} \mathrm{F} / \mathrm{min} ; C$, heated at $150^{\circ} \mathrm{F} / \mathrm{min} ; D$, heated at $4^{\circ} \mathrm{F} / \mathrm{min}$. Etched with 1-percent nital, $\times 100$. 

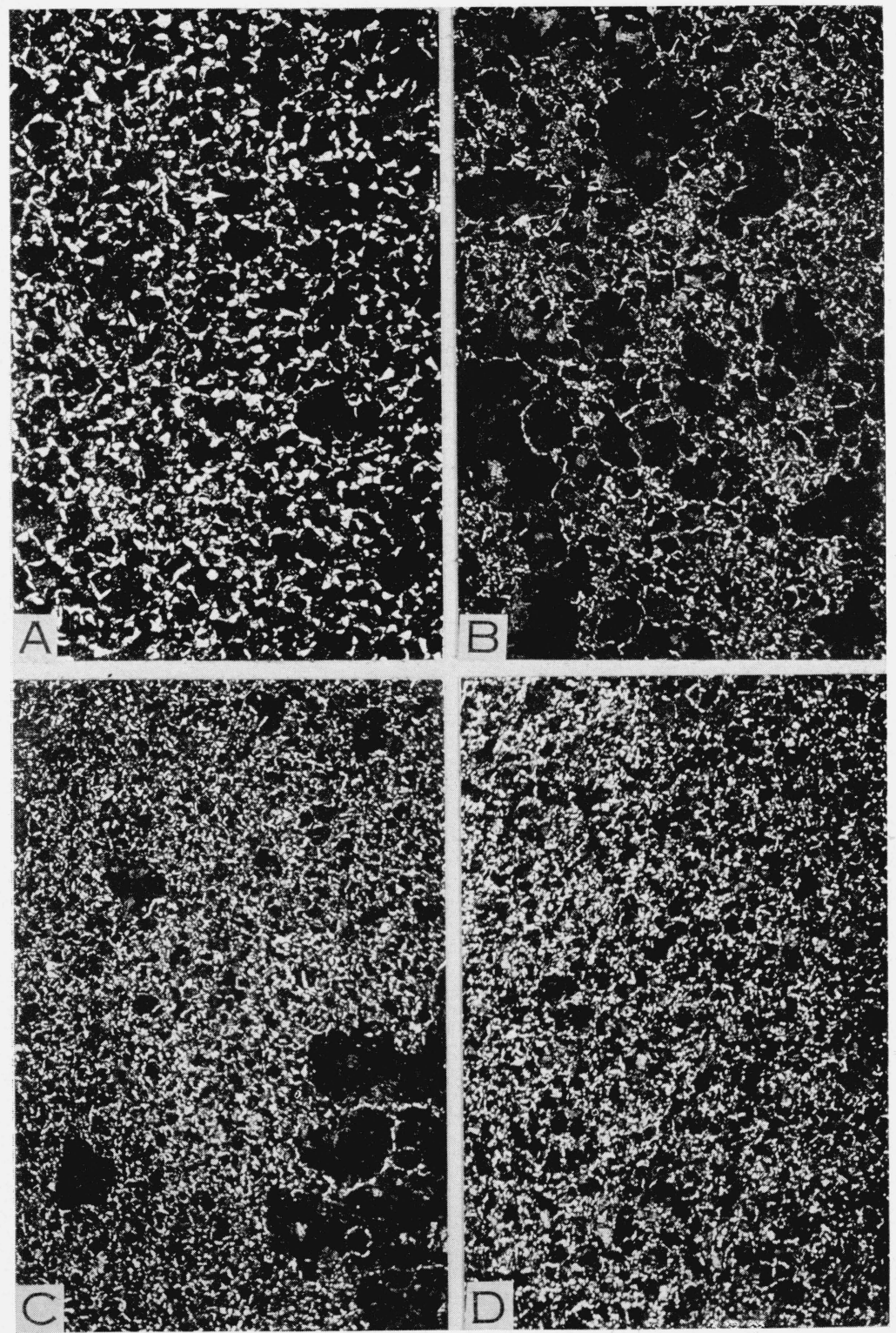

Figure 28.-Austenitic grain size at $1,600^{\circ} \mathrm{F}$ of controlled steel $\mathrm{C}-2$ with initial structure of bainite.

$A$, heated in lead bath; $B$, heated at $830^{\circ} \mathrm{F} / \mathrm{min} ; C$, heated at $120^{\circ} \mathrm{F} / \mathrm{min} ; D$, heated at $7^{\circ} \mathrm{F} / \mathrm{min}$. Etched with 1-percent nital, $\times 100$. 


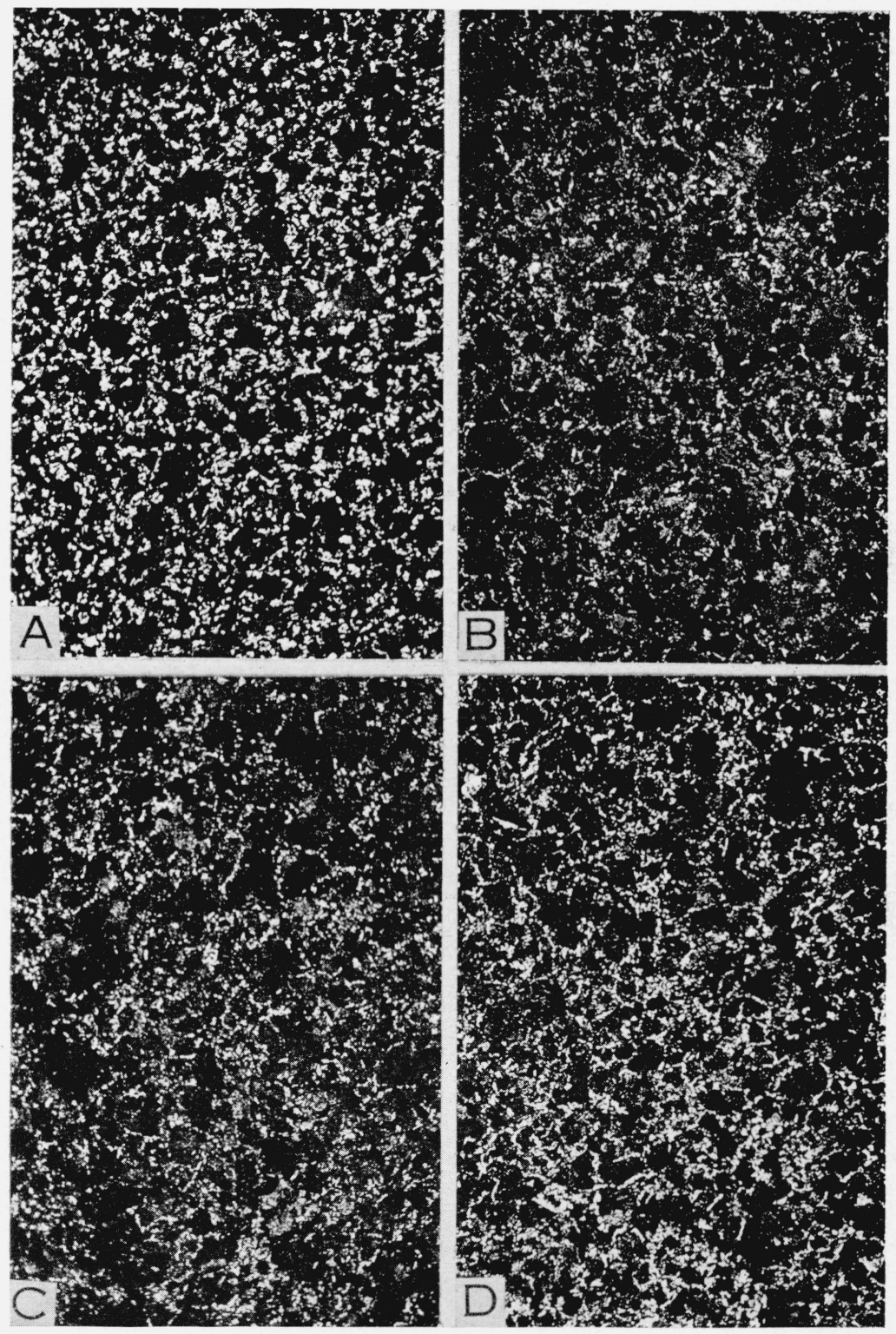

FiguRE 29.-Austenitic grain size at $1,600^{\circ} \mathrm{F}$ of controlled steel $C-2$ with initial structure of spheroidized cementite.

$A$, heated in lead bath; $B$, heated at $1,500^{\circ} \mathrm{F} / \mathrm{min} ; C$, heated at $130^{\circ} \mathrm{F} / \mathrm{min} ; D$, heated at $7^{\circ} \mathrm{F} / \mathrm{min}$. Etched with 1-percent nital, $\times 100$. 

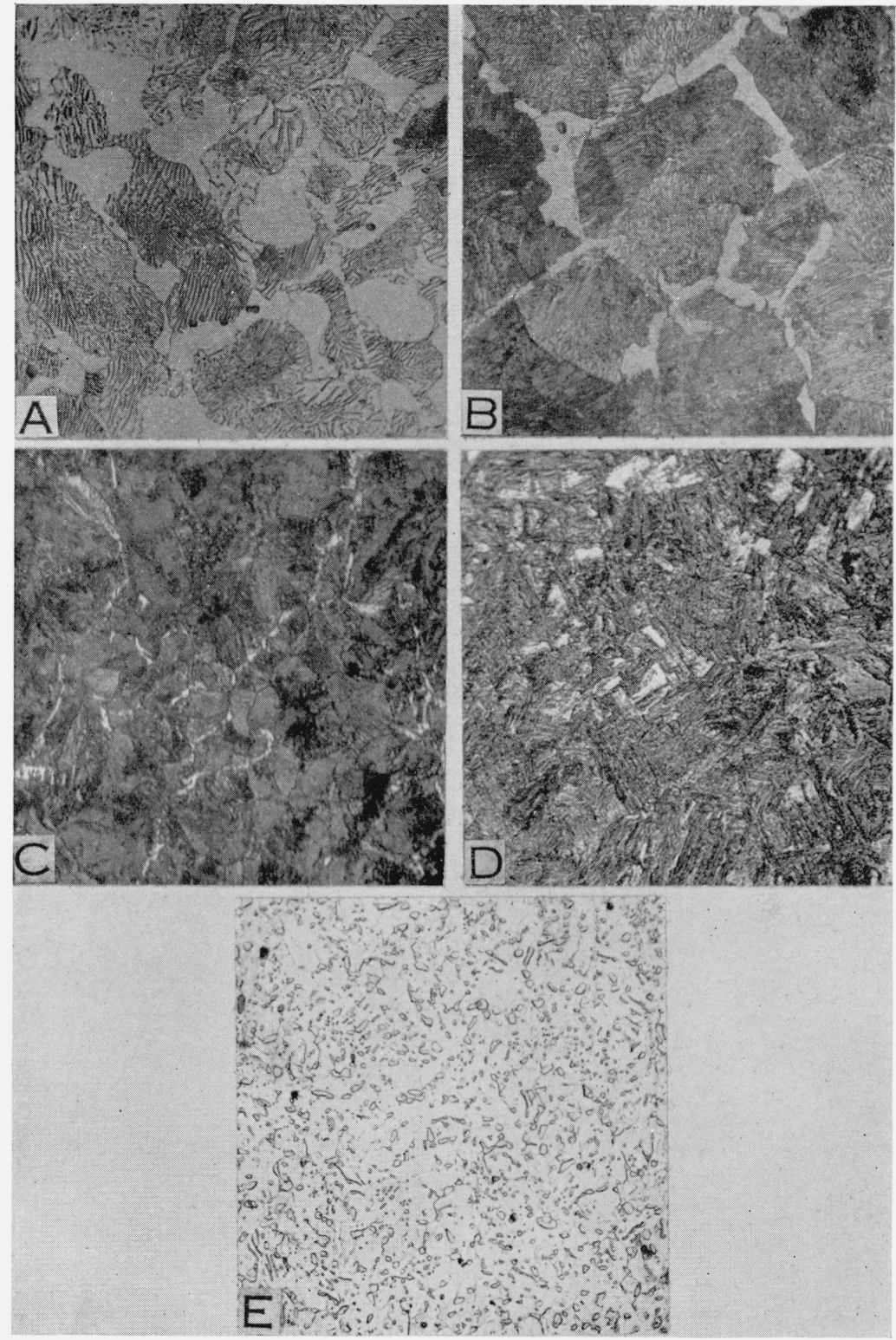

Figure 3.-Initial structures of controlled steel $C$-2.

$A$, coarse pearlite; $B$, medium pearlite; $C$, fine pearlite; $D$, bainite; $E$, spheroidized cementite. Etched with 1-percent nital, $\times 500$ 

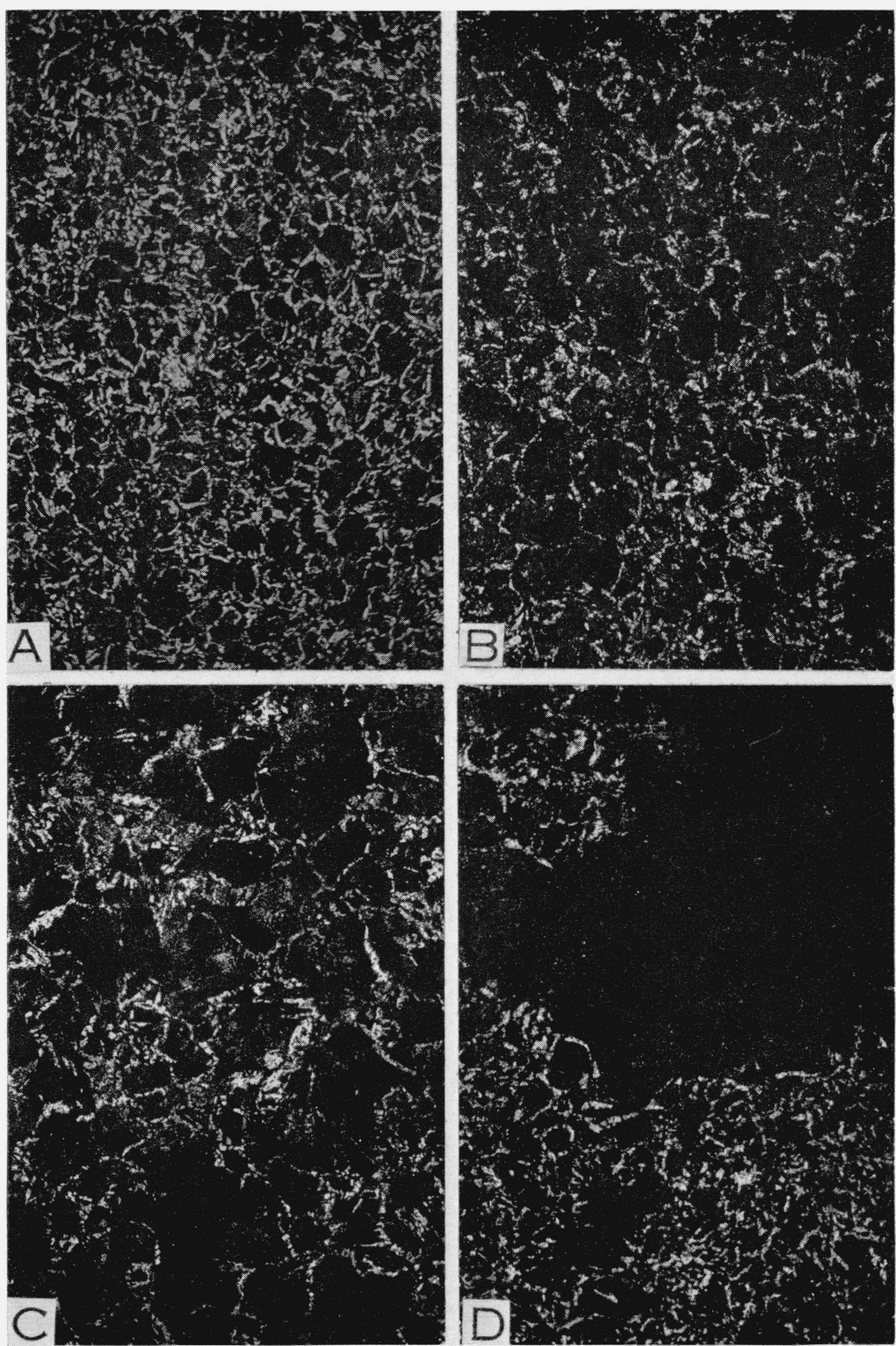

Figure 4.-Austenitic grain size at $1,475^{\circ} F$ of iron-carbon alloy with initial structure of coarse pearlite.

$A$, heated in lead bath; $B$, heated at $540^{\circ} \mathrm{F} / \mathrm{min} ; C$, heated at $80^{\circ} \mathrm{F} / \mathrm{min} ; D$, heated at $5^{\circ} \mathrm{F} / \mathrm{min}$. Etched with 1-percent nital, $\times 100$. 

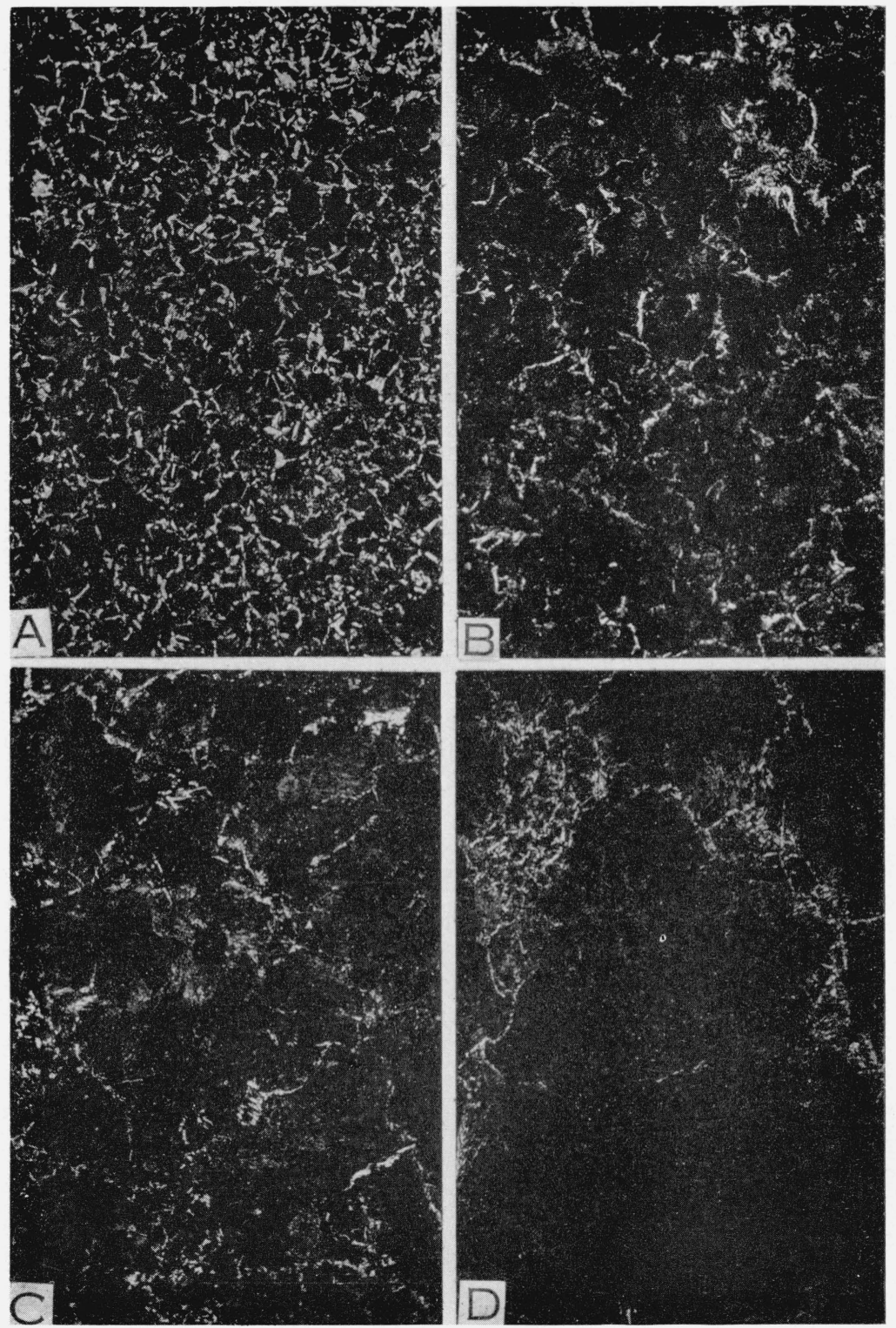

Figure 5.-Austenitic grain size at $1,475^{\circ} F$ of iron-carbon alloy with initial structure of fine pearlite.

$A$, heated in lead bath; $B$, heated at $620^{\circ} \mathrm{F} / \mathrm{min} ; C$, heated at $80^{\circ} \mathrm{F} / \mathrm{min} ; D$, heated at $8^{\circ} \mathrm{F} / \mathrm{min}$. Etched with 1-percent nital, $\times 100$. 

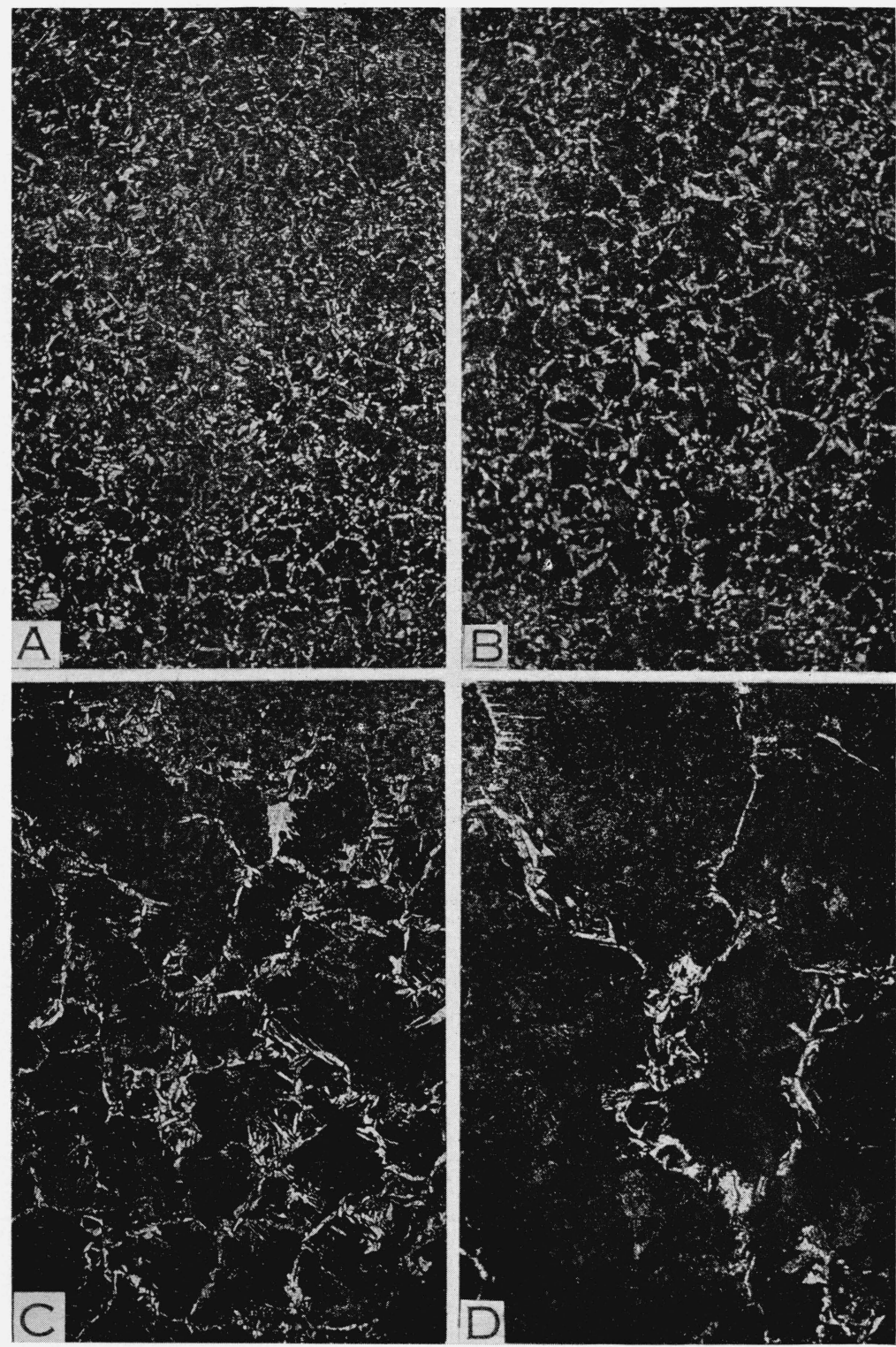

FIGURE 6.-Austenitic grain size at $1,475^{\circ} F$ of iron-carbon alloy with initial structure of spheroidized cementite.

$A$, heated in lead bath; $B$, heated at $1,070^{\circ} \mathrm{F} / \mathrm{min} ; C$, heated at $80^{\circ} \mathrm{F} / \mathrm{min} ; D$, heated at $5^{\circ} \mathrm{F} / \mathrm{min}$. Etched with 1-percent nital, $\times 100$. 

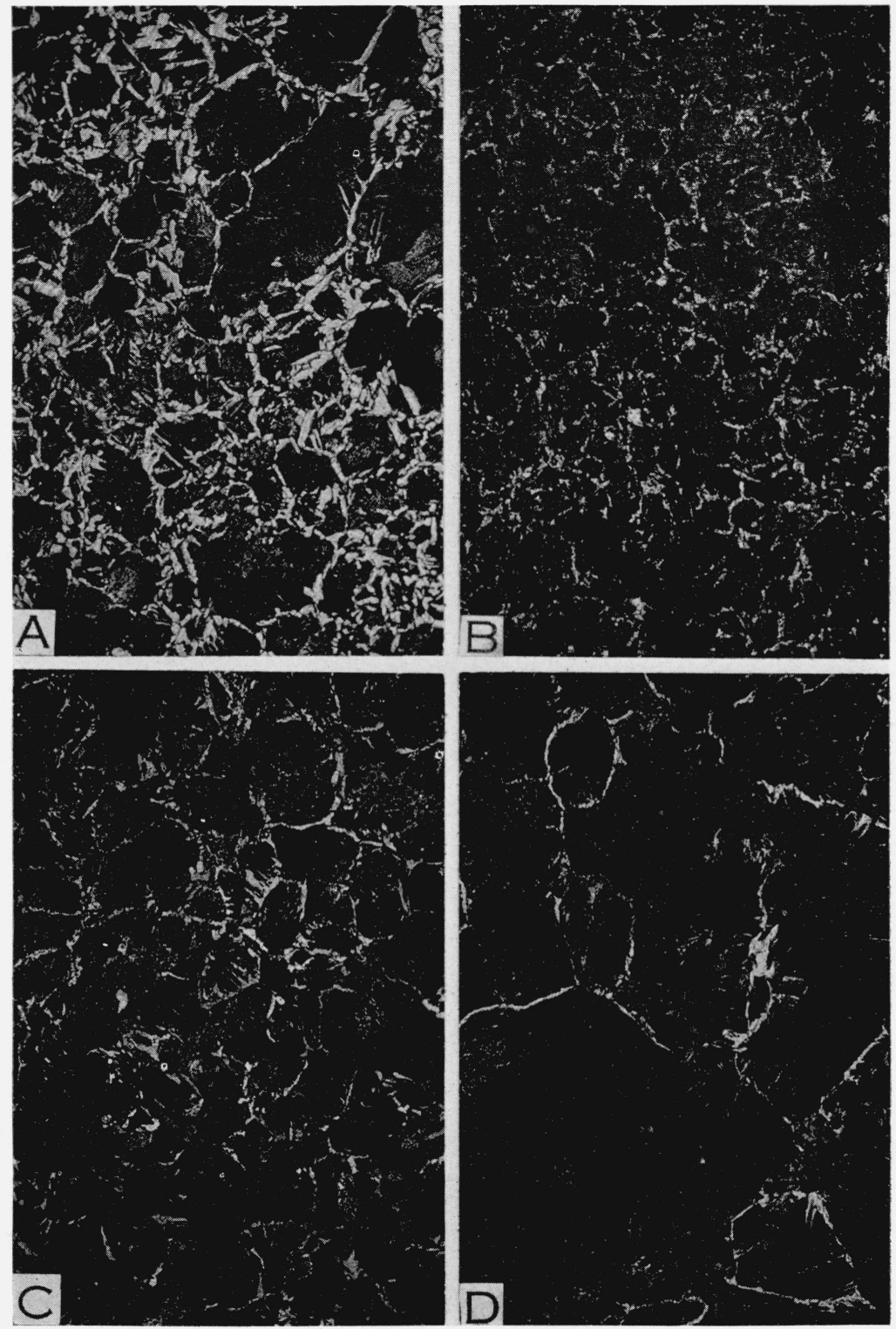

Figure 7.-Austenitic grain size at $1,600^{\circ} F$ of iron-carbon alloy with initial structure of coarse pearlite.

$A$, heated in lead bath; $B$, heated at $1,070^{\circ} \mathrm{F} / \mathrm{min} ; C$, heated at $130^{\circ} \mathrm{F} / \mathrm{min} ; D$, heated at $5^{\circ} \mathrm{F} / \mathrm{min}$. Etched with 1-percent nital, $\times 100$. 

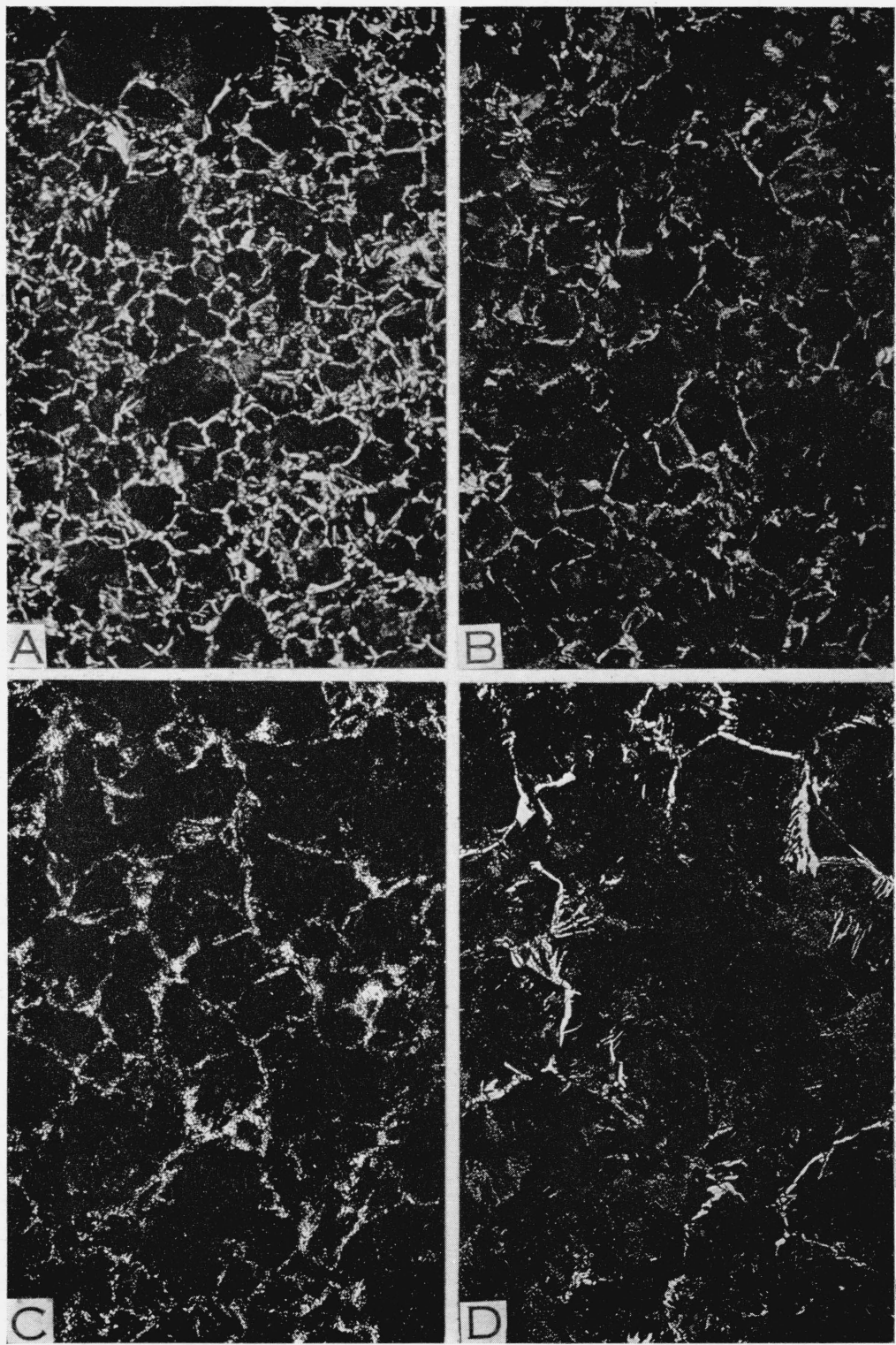

FIGURE 8.-Austenitic grain size at $1,600^{\circ} \mathrm{F}$ of iron-carbon alloy with initial structure of fine pearlite.

$A$, heated in lead bath; $B$, heated at $1,500^{\circ} \mathrm{F} / \mathrm{min} ; C$, heated at $280^{\circ} \mathrm{F} / \mathrm{min} ; D$, heated at $3^{\circ} \mathrm{F} / \mathrm{min}$. Etched with 1-percent nital, $\times 100$ 

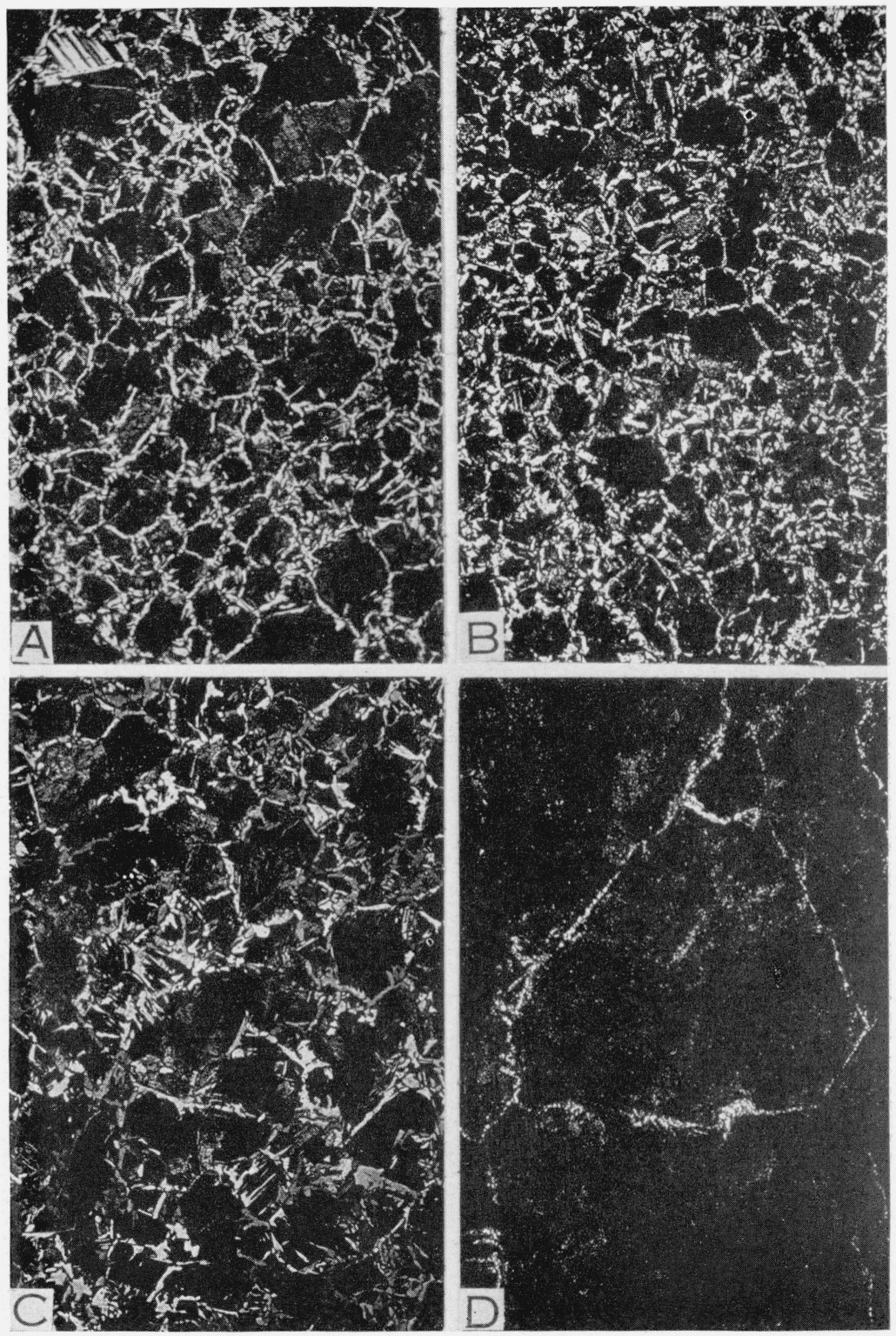

Figure 9.-Austenitic grain size at $1,600^{\circ} F$ of iron-carbon alloy with initial structure of spheroidized cementite.

$A$, heated in lead bath; $B$, heated at $1,250^{\circ} \mathrm{F} / \mathrm{min} ; C$, heated at $150^{\circ} \mathrm{F} / \mathrm{min} ; D$, heated at $5^{\circ} \mathrm{F} / \mathrm{min}$. Etched with 1-percent nital, $\times 100$. 


\section{RESULTS}

\section{IRON-CARBON ALLOY}

The interlamellar spacing of the pearlite or the form and distribution of the carbides in the initial structures had no appreciable influence on the grain sizes established at $1,475^{\circ}$ and $1,600^{\circ} \mathrm{F}$ in the high-purity alloy of iron and carbon (figs. 4 to 9 ).

With each initial structure investigated, relatively fine grains were obtained at $1,475^{\circ} \mathrm{F}$, provided the rate of heating was extremely fast. The grain size at this temperature, however, increased with decrease in the rate of heating until extremely coarse grains (ASTM grain No. -2 to 1 ) were produced. The coarse-grained specimens often contained areas of coalesced ferrite (fig. $5, D$ ).

At $1,600^{\circ} \mathrm{F}$, the average size of the grains obtained also was a minimum when the rate of heating was rapid (fig. $7, B ; 8, A$; and $9, B$ ), although the fastest rate did not produce the smallest grains when the initial structure was either coarse pearlite or spheroidized cementite. The specimens heated in a lead bath (fastest rate) always showed mixed-size grains at $1,600^{\circ} \mathrm{F}$, some of the grains being very coarse (figs. $7, A ; 8, A$; and $9, A$ ). With slow rates of heating; coarse grains of the same order of magnitude were obtained at all temperatures $\left(1,475^{\circ}\right.$ and $\left.1,600^{\circ} \mathrm{F}\right)$ and with all initial structures (coarse pearlite, fine pearlite, and spheroidized cementite).

It is apparent that the dominant factor in establishing the grain size in this iron-carbon alloy, either at $1,475^{\circ}$ or $1,600^{\circ} \mathrm{F}$, was the rate of heating and not the initial structure. The effect of the rate of heating was so pronounced that it also overshadowed the effect of the austenitizing temperature. Although it is generally understood that the higher the temperature, the coarser the austenitic grain size, it was possible to produce considerably coarser grains in this alloy at $1,475^{\circ} \mathrm{F}$, merely by heating slowly, than at $1,600^{\circ} \mathrm{F}$ by heating rapidly.

\section{NONCONTROLLED STEEL}

The influence of initial structure and rate of heating on the grain sizes at $1,475^{\circ}$ and $1,600^{\circ} \mathrm{F}$ of the noncontrolled steel $(C-1)$ is shown in figures 10 to 19 , inclusive.

With the fastest rate of heating, slightly coarser grains were obtained at $1,475^{\circ} \mathrm{F}$ with initial structures of fine pearlite or bainite (figs. 12 , $A$; and $13, A A$ ) than with coarse or medium pearlite or spheroidized cementite (fig:s. $10, A ; 11, A ;$ and $14, A$ ). The observed difference was not considered significant, however, because its order of magn itude was no greater than that obtained with duplicate specimens, as for example, with an initial structure of bainite (fig. 13, $A$ and $A A$ ). With the slowest rates, however, finer grains were obtained at $1,475^{\circ}$ $\mathrm{F}$ with initial structures consisting of medium pearlite, fine pearlite, and bainite (figs. $11, D ; 12, D$; and $13, D$ ), than were obtained with coarse pearlite or spheroidized cementite (figs. $10, D$; and $14, D$ ). With intermediate rates, a grain-size contrast was often obtained in this steel.

The rate of heating showed some minor influence on the grain size at $1,475^{\circ} \mathrm{F}$ when the initial structure was medium pearlite, fine pearlite, or bainite (figs. 11, 12, and 13), but was without effect when the initial structure was coarse pearlite or spheroidized cementite (figs. 10 and 14). 
The grain size of this steel at $1,600^{\circ} \mathrm{F}$ was not markedly affected by variations in the initial structure or rate of heating, although some minor variations in grain size were observed.

\section{CONTROLLED STEEL}

The influence of initial structure and rate of heating on the grain size at $1,475^{\circ}$ and $1,600^{\circ} \mathrm{F}$ of the controlled steel $(C-2)$ is shown in figures 20 to 29 , inclusive.

Although variations in the initial structure influenced the grain size of this steel at $1,475^{\circ}$ and $1,600^{\circ} \mathrm{F}$, the effects observed depended chiefly upon the rate of heating; no definite relation could be established between the initial structure and the grain size at either of these temperatures. For example, with the fast rates of heating, somewhat finer grains were obtained at both $1,475^{\circ}$ and $1,600^{\circ} \mathrm{F}$ when the initial structure was coarse pearlite (figs. 20, $A$, and $B$; and $25, B$ ) than when the initial structures were medium pearlite, fine pearlite, bainite, or spheroidized cementite; but with the slowest rates of heating, the finest grains were obtained with initial structures of fine pearlite and bainite (figs. 22, D;23,D;27,D; and 28,D). Occasionally, particularly with intermediate rates of heating, marked contrast in the grain size was obtained in this steel.

The grain size at $1,475^{\circ} \mathrm{F}$ was influenced by the rate of heating, regardless of the initial structure (figs. $20,21,22,23$, and 24). The grain size at $1,600^{\circ} \mathrm{F}$ was also influenced by the rate of heating when the initial structure was either medium pearlite, fine pearlite, or bainite (figs. 26, 27, and 28). In all cases where the rate of heating influenced the grain size of this steel, the finest grains were obtained with slow rates, a relationship which is the reverse of that obtained with the iron-carbon alloy.

It is noteworthy that by varying the rates of heating, finer grains may be obtained in this controlled steel at $1,600^{\circ} \mathrm{F}$ than at $1,475^{\circ} \mathrm{F}$.

\section{DISCUSSION OF RESULTS}

It is apparent that both initial structure and rate of heating can affect the grain size at a particular temperature. Of these two variables, the data presented in this paper indicate that the rate of heating is the more important. The effect of this variable is pronounced in the case of the iron-carbon alloy investigated. Although very rapid rates of heating result in the formation of rather small austenitic grains in this alloy, very slow rates of heating cause the formation of extremely coarse grains.

From a commercial viewpoint, fortunately, the two steels investigated did not exhibit a similar phenomenon. Slight differences in grain size were obtained with variations in initial structure and rate of heating. A definite correlation between initial structure and grain size could not be established. However, some indication of a correlation between the rate of heating and the grain size could be observed; the slow rates often caused the formation of the smaller austenitic grains. This trend was slight in the case of the noncontrolled steel, but was more marked in the controlled steel. Attention should be directed to the fact that the rate of heating not only had a much more pronounced effect upon the grain size of the iron-carbon alloy than upon the steels, but that the effect was opposite in the two materials. 
It is realized that the iron-carbon alloy and the steels differed widely from each other in chemical composition, especially with regard to $\mathrm{P}, \mathrm{S}, \mathrm{Mn}, \mathrm{Si}, \mathrm{Al}$, and gaseous elements, and that the ironcarbon alloy was relatively free from materials that are classified as grain-growth inhibitors. Although the observed difference in behavior must be attributed to these differences in chemical composition, the present results do not show which of the elements, either individually or in combination, are responsible.

The iron-carbon alloy used in this investigation is being utilized in a study of the mechanism of the transformation of different initial structures to austenite. The results of preliminary tests indicate that the austenitic grains initially formed in this alloy are relatively small regardless of the rate of heating and that the grains grow rapidly in the transformation-temperature range.

The controlled steel was relatively fine-grained in the McQuaidEhn test (ASTM grain No. 8), whereas the noncontrolled steel was coarse-grained (ASTM grain No. 3). It is interesting, therefore, to observe that the controlled steel (fine-grained when carburized at $1,700^{\circ} \mathrm{F}$ ) may have some coarse grains at the recommended quenching temperature of $1,475^{\circ} \mathrm{F}$. (figs. $22, B$; and $23, B$ ) or at the normalizing temperature of $1,600^{\circ} \mathrm{F}$ (figs. $26, B ; 27, B ; 28, B$; and $28, C$ ).

\section{SUMMARY}

A study was made of the influence of initial structure and rate of heating on the grain sizes at $1,475^{\circ}$ and $1,600^{\circ} \mathrm{F}$ of a high-purity alloy of iron and carbon and two plain carbon steels each containing about 0.5 percent of carbon. The two steels were commercial heats which differed principally in the amounts of alumina and aluminum. The steel with the lower percentage of aluminum was produced under conditions which resulted in noncontrol of the austenitic grain size, whereas the other heat was produced under conditions intended to control the grain size.

The different initial structures (that is, the structure that existed just prior to heating to the temperature establishing the grain size) consisted of either coarse pearlite, fine pearlite or spheroidized cementite in the iron-carbon alloy and either coarse pearlite, medium pearlite, fine pearlite, bainite, or spheroidized cementite in each of the commercial steels.

Wide variations in the rate of heating were obtained by plunging small specimens into a lead bath or by heating them in vacuum. Except for the specimens heated in lead (most rapid rates), the rate of heating was taken as the average rate to heat from $1,325^{\circ}$ to $1,450^{\circ} \mathrm{F}$, which included the transformation-temperature range.

Variations in the initial structure of the iron-carbon alloy had no appreciable effect on the grain size at $1,475^{\circ}$ or $1,600^{\circ} \mathrm{F}$. Although the initial structure had some influence on the grain size of the commercial steels, no definite correlation was found between the grain size and the interlamellar spacing of pearlite, or the form and distribution of carbides.

The rate of heating had a marked influence on the grain sizes at $1,475^{\circ}$ and $1,600^{\circ} \mathrm{F}$ of the iron-carbon alloy. At each temperature relatively fine grains were produced by rapid heating and coarse grains by slow heating. 
With some of the initial structures, the rate of heating affected the grain size at $1,475^{\circ} \mathrm{F}$ in the noncontrolled and controlled steels, and at $1,600^{\circ} \mathrm{F}$ in the controlled steel. In all cases where the rate of heating influenced the grain size of the commercial steels, the finest grains were obtained with slow rates, the reverse of the relation found with the iron-carbon alloy.

Washington, March 18, 1942. 